\title{
Robust Amyloid Clearance in a Mouse Model of Alzheimer's Disease Provides Novel Insights into the Mechanism of Amyloid- $\beta$ Immunotherapy
}

\author{
Allan Wang, ${ }^{1,2}$ Pritam Das, ${ }^{6}$ Robert C. Switzer III, ${ }^{7}$ Todd E. Golde, ${ }^{8}$ and Joanna L. Jankowsky ${ }^{2,3,4,5}$ \\ ${ }^{1}$ Department of Psychology, Rice University, Houston, Texas 77251, Departments of ${ }^{2}$ Neuroscience, ${ }^{3}$ Neurosurgery, and ${ }^{4}$ Neurology, and ${ }^{5} \mathrm{Huffington}$ \\ Center on Aging, Baylor College of Medicine, Houston, Texas 77030, ${ }^{6}$ Department of Neuroscience, Mayo Clinic Florida, Jacksonville, Florida 32224, \\ ${ }^{7}$ NeuroScience Associates, Knoxville, Tennessee 37934, and ${ }^{8}$ Department of Neuroscience, McKnight Brain Institute, Center for Translational Research in \\ Neurodegenerative Disease, University of Florida, Gainesville, Florida 32610
}

Many new therapeutics for Alzheimer's disease delay the accumulation of amyloid- $\beta(\mathrm{A} \beta)$ in transgenic mice, but evidence for clearance of preexisting plaques is often lacking. Here, we demonstrate that anti-A $\beta$ immunotherapy combined with suppression of $A \beta$ synthesis allows significant removal of antecedent deposits. We treated amyloid-bearing tet-off APP (amyloid precursor protein) mice with doxycycline to suppress transgenic $\mathrm{A} \beta$ production before initiating a 12 week course of passive immunization. Animals remained on doxycycline for 3 months afterward to assess whether improvements attained during combined treatment could be maintained by monotherapy. This strategy reduced amyloid load by $52 \%$ and $A \beta 42$ content by $28 \%$ relative to pretreatment levels, with preferential clearance of small deposits and diffuse $A \beta$ surrounding fibrillar cores. We demonstrate that peripherally administered anti-A $\beta$ antibody crossed the blood- brain barrier, bound to plaques, and was still be found associated with a subset of amyloid deposits many months after the final injection. Antibody accessed the brain independent of plasma A $\beta$ levels, where it enhanced microglial internalization of aggregated $\mathrm{A} \beta$. Our data support a mechanism by which passive immunization acts centrally to stimulate microglial phagocytosis of aggregated $\mathrm{A} \beta$, but is opposed by the continued aggregation of newly secreted $\mathrm{A} \beta$. By arresting the production of $\mathrm{A} \beta$, combination therapy allows microglial clearance to work from a static amyloid burden toward a significant reduction in plaque load. Our findings suggest that combining two therapeutic approaches currently in clinical trials may improve neuropathological outcome over either alone.

\section{Introduction}

The amyloid hypothesis for Alzheimer's disease (AD) predicts that slowing the accumulation of amyloid- $\beta(\mathrm{A} \beta)$ before damage ensues will slow the progression of cognitive decline (Hardy and Higgins, 1992; Hardy, 2009). Given this, considerable effort has been devoted to developing drugs that reduce production of $\mathrm{A} \beta$ or enhance its clearance from the brain. Patients with AD carry extensive amyloid neuropathology (Forsberg et al., 2008; Okello et al., 2009; Wolk et al., 2009); thus, therapies aimed at A $\beta$ may be most successful if they can remove preexisting deposits. Although many studies have documented the functional consequences of exposure to soluble A $\beta$ aggregates (Shankar and Walsh, 2009; Ondrejcak et al., 2010; Palop and Mucke, 2010), their insoluble aftermath is not benign. Amyloid deposits cause physical and

Received Sept. 23, 2010; revised Jan. 13, 2011; accepted Jan. 21, 2011.

This work was funded by Alzheimer's Association Grant NIRG 062582 through The Straus Family Fund (J.L.J.), National Institute of Aging Grants K01 AG026144 (J.L.J.) and R01 AG018454 (T.E.G.), and National Institutes of Health Director's New Innovator Award DP2 0D001734(J.L.J.). We thank Julie Switzer of NeuroScience Associates for overseeing the multibrain histology, Sidali Benazouz and Beth Olsen at Caltech and Anna Gumpel at Baylor College of Medicine for animal care, Bernard Lee and Bernard Kuecking at Zeiss for guidance on microscopy and image analysis, and Eddie Koo for helping this study get off the ground.

Correspondence should be addressed to Joanna L. Jankowsky, Department of Neuroscience, BCM295, Baylor College of Medicine, One Baylor Plaza, Houston, TX 77030. E-mail: jankowsk@bcm.edu.

DOI:10.1523/JNEUROSCI.5077-10.2011

Copyright $\odot 2011$ the authors $\quad 0270-6474 / 11 / 314124-13 \$ 15.00 / 0$ functional changes in local neurons that impact long-range communication in the brain (Le et al., 2001; D'Amore et al., 2003; Stern et al., 2004; Tsai et al., 2004; Busche et al., 2008; Kuchibhotla et al., 2008; Meyer-Luehmann et al., 2008). Plaque formation also incites a dramatic immune response which may further contribute to neuronal dysfunction (Jucker and Heppner, 2008). Thus, an ideal treatment for AD may need not only to prevent additional $\mathrm{A} \beta$ aggregation but also to clear preexisting amyloid.

Multiple anti-A $\beta$ therapeutics are currently in development or clinical trials. Drugs designed to decrease $\mathrm{A} \beta$ production include $\beta$ - and $\gamma$-secretase inhibitors, $\gamma$-secretase modulators, and $\alpha$-secretase activators (De Strooper et al., 2010). Aggregation inhibitors and plaque busters are being tested to improve $\mathrm{A} \beta$ clearance (Golde et al., 2010). Considerable effort has also focused on inactivating $A \beta$ through immunotherapy by active vaccination against the peptide or passive immunization with anti-A $\beta$ antibodies (Brody and Holtzman, 2008). Each of these approaches attenuates the progression of amyloid formation in amyloid precursor protein (APP) transgenic mice (Abramowski et al., 2008; Garcia-Alloza et al., 2009). However, only direct intracranial delivery of anti-A $\beta$ antibody-a route of administration unlikely to be used in a clinical setting - has been definitively shown to clear preexisiting deposits (Bacskai et al., 2001; Wilcock et al., 2003; Oddo et al., 2004; Brendza et al., 2005; Maeda et al., 2007). 
Preclinical studies have not yet evaluated the possibility of combining multiple anti-A $\beta$ therapies in the treatment of $\mathrm{AD}$. Combination treatments have become the standard of care for several diseases, including HIV/AIDS and cancer. We have previously shown that two models of monotherapy now in clinical trials - suppression of A $\beta$ synthesis (Jankowsky et al., 2005) and passive immunization with anti- $\mathrm{A} \beta$ antibodies (Levites et al., 2006a,b) — could arrest but not reverse amyloid pathology in transgenic mice. We reasoned that reducing the production of $\mathrm{A} \beta$ before passive antibody transfer might allow one treatment to improve efficacy of the other. We now demonstrate that this combination approach results in significant amyloid clearance from animals harboring substantial preexisting pathology.

\section{Materials and Methods}

Mice

Two tet-responsive APP transgenic lines, tetO-APPswe/ind lines 102 and 107, overexpressing similar levels of APP were used for study [The Jackson Laboratory; 7051 and 7052 (Jankowsky et al., 2005)]. Each line was mated to CaMKII $\alpha$-tTA line B [The Jackson Laboratory; 3010 (Mayford et al., 1996)] and resulting double-transgenic male offspring were mated with wild-type females (C57BL/6J for line 102 and $\mathrm{F}_{1} \mathrm{C} 3 \mathrm{~B} 6$ for line 107) to produce experimental cohorts.

\section{Doxycycline administration}

Long-term treatment at 6 months (line 107). Doxycycline (dox) treatment was started at 6 months of age and continued until harvest either 2 weeks or 6 months later. Dox was administered via chow containing $200 \mathrm{mg} / \mathrm{kg}$ antibiotic (S3888 or F4845; BioServ).

Long-term treatment at 18 months (line 107). Animals were reared on dox by feeding medicated chow to mating pairs. Offspring were maintained on dox until 12 months of age, and then switched to unmedicated chow to induce transgene expression for 6 months before being returned to dox from 18 months until harvest.

Short-term treatment at 7 months (line 102). Dox was started at 7 months of age and continued until harvest 3.5 weeks later. Because line 102 is more responsive to dox than line 107, chow formulation was reduced to $50 \mathrm{mg} / \mathrm{kg}$ antibiotic (F5903; BioServ).

\section{Antibody injections}

Two weeks after starting on dox, mice received the first of 2 or 12 weekly intraperitoneal injections containing $500 \mu \mathrm{g}$ of mouse IgG, either as purified anti-A $\beta 1-16$ monoclonal IgG2a antibody Ab9 (Levites et al., 2006b) or as nonspecific mouse IgG (SLM66; Equitech Bio).

\section{Tissue harvest}

Animals were perfused with PBS, and the isolated brains were hemisected along the midline. One hemisphere was frozen for $A \beta$ analysis; the other hemisphere was immersion-fixed for $48 \mathrm{~h}$ at $4^{\circ} \mathrm{C}$ in $4 \%$ paraformaldehyde.

\section{Plasma sampling}

Whole-blood samples were collected by submandibular bleed before treatment and again after 2 weeks on either dox or regular chow. Blood was harvested into EDTA-charged tubes and plasma isolated by centrifugation.

\section{ELISA}

Hemi-forebrain samples were prepared for analysis of $A \beta$ levels by twostep sequential extraction using $2 \%$ SDS followed by $70 \%$ formic acid (FA) as previously described (Jankowsky et al., 2007). Plasma samples were used neat. $A \beta$ levels were determined by end-specific sandwich ELISAs using $\mathrm{mAb} 2.1 .3$ for capture (human $\mathrm{A} \beta \mathrm{x}-42$ specific) and HRPconjugated $\mathrm{mAb} \mathrm{Ab} 9$ (human $\mathrm{A} \beta 1-16$ specific) for detection, or $\mathrm{mAb}$ Ab9 for capture and HRP-conjugated mAb 13.1.1 (human A $\beta \mathrm{x}-40$ specific) for detection (Levites et al., 2006a,b). All values were calculated as picomoles per gram based on the initial weight of brain tissue. Serum concentrations were baseline corrected by subtracting the average nonspecific signal detected in TTA single-transgenic mice.

\section{Immunoblotting}

The 2\% SDS homogenates prepared for ELISA were diluted 1:1 with $2 \times$ concentrated high-detergent RIPA buffer minus SDS $(2 \times$ PBS, $1 \%$ deoxycholate, 1\% NP-40, 5 mм EDTA, plus protease inhibitors). Approximately $25 \mu \mathrm{g}$ of the resulting homogenate was separated on a $10.5-14 \%$ Tris-glycine gel (Bio-Rad criterion) and transferred to nitrocellulose. The upper part of the blot was probed with anti-human APP/A $\beta$ antibody 6E10 (1:5000; Signet; 9300-02), and the lower part with an antiSOD1 polyclonal (1:2500; Assay Designs; SOD1). Binding was detected with HRP-labeled secondary antibodies and developed with ECL reagent. Chemiluminescence was measured with a Fuji LAS-4000 miniCCD system and quantified using MultiGauge software.

\section{Histology}

Immersion-fixed hemibrains were cryoprotected, frozen, and sectioned at $35 \mu \mathrm{m}$. Brains were either cut individually in the saggital plane or embedded 32 per block in a solid matrix and sectioned coronally (MultiBrain processing by NeuroScience Associates). Sections were stored in cryoprotectant at $-20^{\circ} \mathrm{C}$ until use.

Campbell-Switzer silver stain. A detailed protocol for this stain can be found online at the NeuroScience Associates website: http://www. neuroscienceassociates.com/Documents/Publications/campbell-switzer_ protocol.htm.

Thioflavine-S. Guntern-modifed thioflavine-S staining was performed as described previously (Jankowsky et al., 2007).

Perls Prussian blue. Sections were placed in a freshly prepared mixture of $2 \%$ $\mathrm{HCl}$ and $2 \%$ potassium ferrocyanide solution for $30 \mathrm{~min}$ at room temperature, refrigerated for $1 \mathrm{~h}$, rinsed in water, mounted, dehydrated, and coverslipped.

\section{Immunohistochemistry (Iba-1, CD68)}

Sections were rinsed, treated with $0.9 \%$ hydrogen peroxide in TBST (TBS plus $0.02 \%$ Triton-X), and blocked with TBST plus $1.5 \%$ goat serum before overnight incubation at room temperature with primary antibody diluted in TBST [Wako rabbit (Rb) anti-Iba1, 019-19741, 1:15,000; or Serotec biotinylated rat anti-CD68, MCA1957BT, 1:400]. Binding was detected with biotin-conjugated secondary antibodies followed by HRPavidin and developed with DAB. A subset of the CD68-immunostained sections were costained with $0.25 \%$ Congo red (Sigma-Aldrich; C6277) and counterstained with $0.01 \%$ hematoxylin.

\section{Immunofluorescence (mouse IgG, mouse IgG1, mouse IgG2a,} 4G8, Iba-1)

Mouse IgG. Sections were rinsed, blocked in TBST plus 5\% donkey (Dk) serum, and then incubated at room temperature for $2 \mathrm{~h}$ in Alexa Fluor 568-conjugated Dk anti-mouse (Ms) IgG (Invitrogen; A10037) diluted 1:200 in block.

Ms IgG plus Iba-1 plus Thioflavine-S. Sections were rinsed and blocked as above, and then incubated overnight at $4^{\circ} \mathrm{C}$ with $\mathrm{Rb}$ anti-Iba- 1 antibody diluted in blocking solution (Wako; Rb anti-Iba-1; 019-19741; 1:500). After rinsing with TBS, sections were incubated for $2 \mathrm{~h}$ at room temperature with Alexa Fluor-conjugated secondary antibodies diluted in blocking solution (Invitrogen; Dk anti-Rb Alexa 647, A31573, 1:400; Dk anti-Ms IgG Alexa $568,1: 200)$. Sections were rinsed in TBS, and then incubated in $0.002 \%$ Thioflavine-S/1× TBS for $8 \mathrm{~min}$, followed by brief rinses in 50\% ethanol.

Ms IgG1 plus Ms IgG2a. Sections were rinsed, blocked in TBST plus 5\% donkey serum and $1 \%$ goat serum, and then incubated at room temperature for $2 \mathrm{~h}$ in Alexa Fluor 488-conjugated goat (Gt) anti-Ms IgG1 (Invitrogen; A21121) and Alexa Fluor 568-conjugated Gt anti-Ms IgG2a (Invitrogen; A21134), each diluted 1:400 in blocking solution.

4 G8 plus Iba-1. Sections were incubated for $1 \mathrm{~min}$ in $80 \%$ formic acid, rinsed in TBS, then blocked in TBST plus $5 \%$ goat serum before overnight incubation at $4^{\circ} \mathrm{C}$ with primary antibody diluted in blocking solution (Signet; Ms anti-A $\beta$ clone 4G8, 9220-05, 1:1000; Wako; Rb anti-Iba-1, 1:500). Binding was detected with Alexa Fluor-conjugated secondary antibodies (Invitrogen; Gt anti-Ms Alexa 488, A11029, 1:400; Gt anti-Rb Alexa 568, A11011, 1:400).

Immediately before use, all antibodies used for immunofluorescence were diluted 1:10 in 50-75 mm reduced glutathione (Sigma-Aldrich; G4251)/TE, $\mathrm{pH} 8.0$, and incubated on ice for $1 \mathrm{~h}$ to decrease nonspecific binding (Rogers et al., 2006). 
Channel levels in all figures have been adjusted in Photoshop to equalize background signal across panels.

\section{Quantitation of histology}

Amyloid burden and microglial activation. Sections were analyzed using a macro written for AxioVision 4.7. Color thresholds were use to identify amyloid plaques or activated microglia in high-resolution digital scans of the stained slides. Background staining and shading artifacts were manually excluded from the analyses. The region of interest was specified by tracing the cortex (6.5 and 12 month animals) or hippocampus (24 month animals) of the corresponding section and the area of pixels above threshold computed relative to the total area for the region of interest. Five [CampbellSwitzer (CS)-silver, 6.5 and 12 months], four (thio-S), or three (CD68 and CS-silver, 24 months) sections spaced at 210 (CS-silver) or $420 \mu \mathrm{m}$ (thio-S and CD68) intervals were measured for each animal.

Vascular amyloid. Amyloid-containing blood vessels were counted manually from CS-silver and thioflavine-S-stained sections. Counts were restricted to cortical layer 1 where penetrating vessels run perpendicular to the pial surface and allow for easy quantitation compared with the complex vascular involvement of deeper cortical layers. Five sections spaced at $420 \mu \mathrm{m}$ intervals were counted for each animal.

Microhemorrhage. The number of perivascular clusters of hemosiderin-positive cells was counted manually from Perls-stained sections under differential interference contrast (DIC) illumination. Eight sections spaced at $420 \mu \mathrm{m}$ intervals were counted for each animal. Severity was estimated by grading each hemorrhage: grade $0,0-1$ cell; grade 1 , clusters of $2-5$ cells; grade 2 , clusters of $6-10$ cells; grade 3 , clusters of $10+$ cells.

\section{Statistics}

All statistics were done using Prism 5.0. Data sets were analyzed for outliers by Grubb's test, which resulted in the removal of no more than one data point per group and no more than two data points per fourgroup comparison. Comparisons of multiple groups (6 month experiment) were done by one-way ANOVA followed by Tukey's post hoc testing. All $p$ values listed are for posttest comparisons. Comparisons limited to two groups (18 month experiment) were done by Student's $t$ test with Welch's correction for unequal variances where appropriate. All graphs display group mean \pm SEM.

\section{Results}

Suppression of $\mathbf{A} \boldsymbol{\beta}$ synthesis enables plaque clearance by passive antibody treatment

We used tet-off APP transgenic mice to test whether therapeutically reducing $A \beta$ production could enhance the efficacy of passive immunization against $\mathrm{A} \beta$ (Fig. $1 a-c$ ). At the outset of treatment, 6-month-old APP/TTA mice had a significant amyloid burden throughout the forebrain, with $7.8 \pm 0.48 \%$ of the cortical surface area covered by amyloid deposits (Fig. $2 a, b$ ). Left untreated, amyloid burden rises almost 10 -fold between 6 and 12 months of age in this transgenic line (63.2\% at 12 months) (Fig. $2 e, f)$. As previously shown (Jankowsky et al., 2005), this increase can be prevented by suppression of transgenic APP. Consistent with our past work, amyloid load in APP/TTA mice treated with dox (dox-only) from 6-12 months was only slightly greater than it had been at the start of treatment 6 months earlier (dox-only, $12.1 \pm 0.58 \%$, vs pretreatment, $7.8 \pm 0.48 \% ; p<0.01$ ). Animals treated with dox and given weekly injections of a nonspecific mouse IgG (dox plus IgG) harbored nearly identical amyloid levels to mice receiving dox alone (13.36 $\pm 1.09 \%)$. Notably, mice treated with dox and given weekly injections of anti-A $\beta$ IgG carried less amyloid than animals harvested before treatment (3.72 $\pm 0.49 \% ; p<0.05)$. Biochemical measurements of $\mathrm{A} \beta$ concentration confirmed that the reduction in amyloid burden came from a decrease in $\mathrm{A} \beta$ (Fig. 3). Mice treated with dox plus Ab9 had $28.0 \%$ less $A \beta 42$ than animals harvested before treatment $(p<0.05)$ (Fig. $2 c$, Table 1$)$. This reduction may be partly attributable to effects on SDS-soluble $\mathrm{A} \beta$, which was $37.3 \%$ lower after combination therapy than pretreatment levels $(p<0.05)$ (Fig. $2 d$, Table 1). The few plaques remaining in these mice were naked cores, stripped of the expansive diffuse amyloid that surrounds plaques in all other conditions. These cores were apparent on thioflavine-S-stained sections and were not significantly affected by treatment (Fig. $4 a, b$ ). Consistent with the thioflavine histology, there was no change in formic acid-extracted $\mathrm{A} \beta$ between groups (Fig. 4c). Given that the majority of $A \beta$ is contained in cored formic acidsoluble deposits, combination treatment provided a much greater reduction in total amyloid load (measured by silver stain) than in total $\mathrm{A} \beta$ content (measured by ELISA).

\section{Combination therapy is equally effective in aged mice}

Our studies clearly demonstrated that combination therapy could reduce amyloid load in young adult transgenic mice (6-12 


\section{a Initial state prior to treatment}
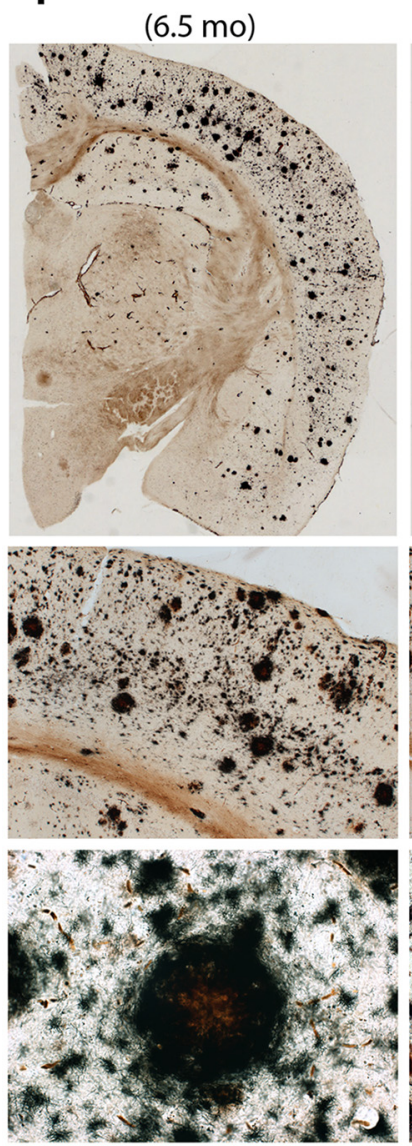

b

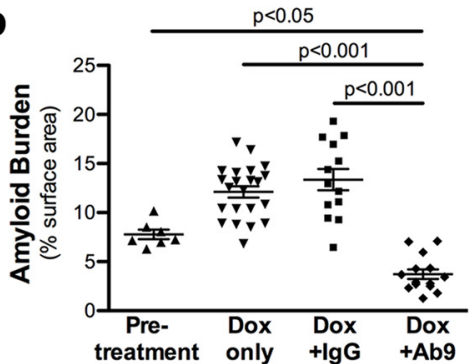

e

6 mo untreated

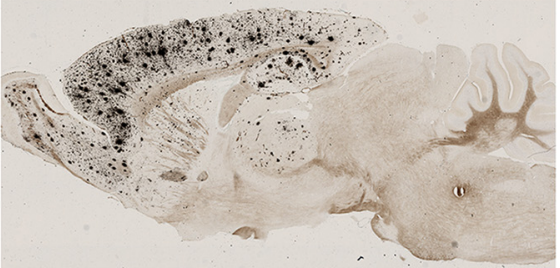

Dox only

(12 mo)
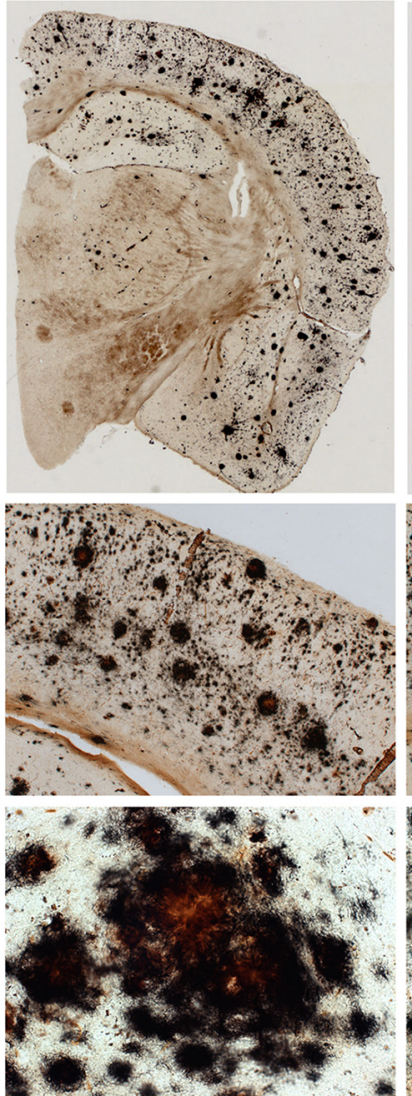

Control lgG + Dox

(12 mo)
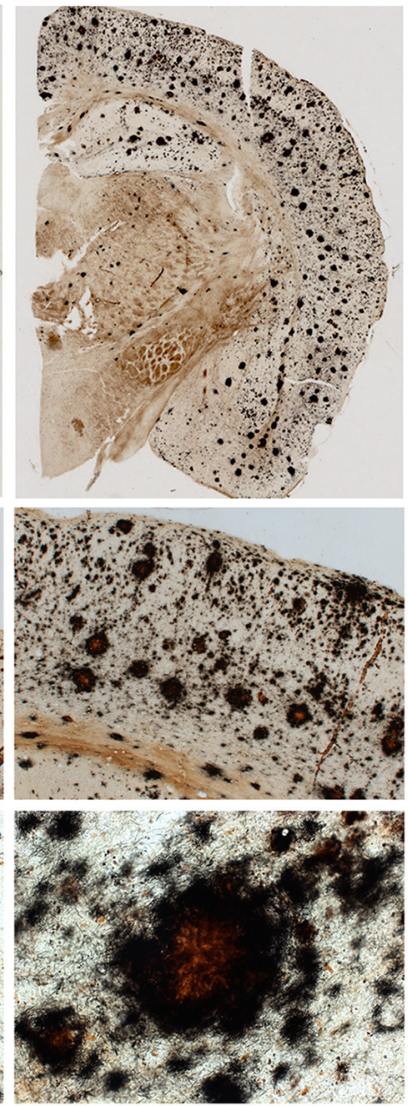

Ab9 + Dox

(12 mo)
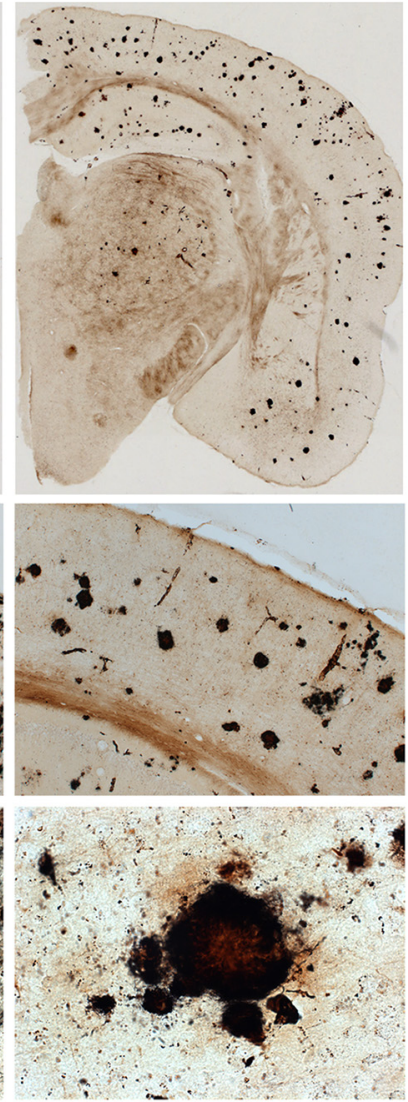

C

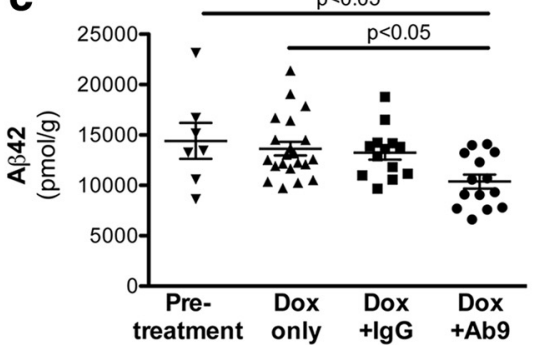

12 mo untreated

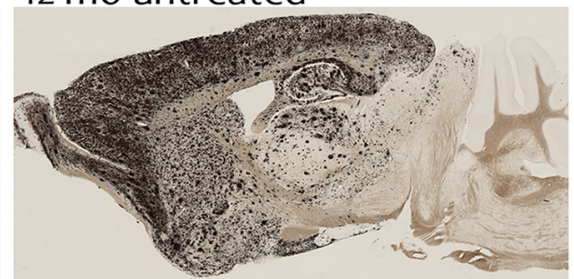

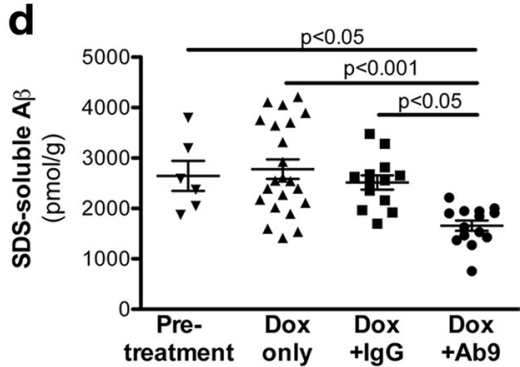

f

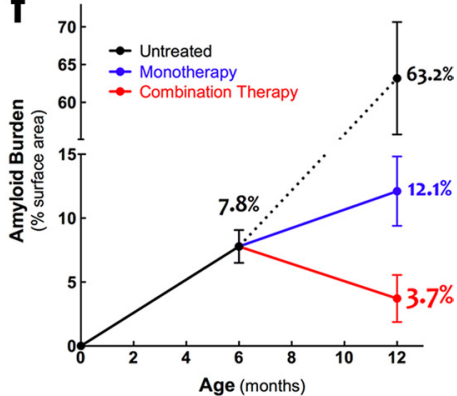

Figure 2. Combination therapy clears amyloid and lowers A $\beta$ levels in transgenic mice. $\boldsymbol{a}$, Silver histology reveals significant amyloid burden throughout the forebrain of APP/TTA transgenic mice harvested at 6.5 months of age (line $107 ; n=7)$. Plaque burden is maintained at this level by treatment with dox $(n=22)$ or a combination of dox plus lgG ( $n=14$ ) but is substantially reduced by dox plus Ab9 ( $n=14)$. Individual plaques in the dox plus Ab9 mice look like naked cores stripped of their diffuse halo (top, $1 \times$; middle, $5 \times$; bottom, $63 \times$ ). $\boldsymbol{b}, 0$ uantitation of plaque load from silver-stained sections confirms that amyloid burden is significantly lower in mice treated with dox plus Ab9 than in age-matched controls or animals harvested before treatment. Other significant comparisons (data not shown) were as follows: pretreatment versus dox only ( $p<0.05$ ), pretreatment versus dox plus lgG ( $p<0.01)$. c, $\boldsymbol{d}, A \beta$ ELISAs confirm the histology. Both $A \beta 42$ [sum of SDSplusFA-extracted 42; (c)] and SDS-solubleA $\beta$ [sum ofSDS-extracted 40 plus 42 (d)] werelower in mice given dox plus Ab9 than they were before treatment or after monotherapy.e, Untreated mice (6-12 months) show the rise in amyloid that would occur without intervention (line 102). $f$, Graph illustrating the relative efficacy of combination therapy. All mice in our study started treatment with a moderate amyloid burden, similar, ifslightly morepronounced, to thelevels expected inAlzheimer's patients at thetime of diagnosis. Leftuntreated, plaqueburden increasesmorethaneightfold overthenext 6 months in thismousemodel. This progression can beslowed considerably by suppressing additional production of $A \beta$, but only a combined approach clears amyloid formed before treatment. 
months of age). However, the effectiveness of our approach in geriatric animals (18-24 months) would serve as a more realistic model of its therapeutic potential in human patients. A major limitation to conducting age-appropriate interventional studies in standard transgenic animals has been that the continued overexpression of APP results in severe plaque burden before midlife. We took advantage of the temporal control provided by the tetoff APP system to overcome this limitation. By suppressing transgenic APP until the mice reached 12 months of age, we were able to generate 18 -month-old mice that carried only 6 months of amyloid load. We then tested the same treatment protocol used in the younger mice (Fig. $5 a$ ).

As in the 6 month study, animals treated at 18 months with a combination of dox plus Ab9 had visibly less amyloid than siblings treated with dox plus nonspecific IgG (Fig. 5b,c). Amyloid burden was $72.3 \%$ lower in dox plus Ab9-treated mice than in controls ( $1.65 \pm 0.18 \%$ dox plus IgG vs $0.455 \pm 0.072 \%$ dox plus Ab9) (Fig. $5 d$ ). Biochemical measures of $\mathrm{A} \beta$ content were consistent with the histology (Fig. 6). The concentration of $A \beta 42$ was $47.1 \%$ lower in the dox plus Ab9 mice $(p<0.005$ after Welch's correction for unequal variances) (Fig. $5 e$, Table 2 ), SDS-soluble A $\beta$ was reduced by $55.6 \%(p<0.01)$ (Fig. $5 f)$, and FA-soluble $\mathrm{A} \beta$ by $44.6 \%(p<0.05)$ (Fig. $5 g$ ). Thus, combination therapy was equally effective in aged animals and in young adults.

\section{Reductions in plaque load can be maintained} by monotherapy

All of the mice tested at 6 and 18 months were continued on dox for 2.5 months after the final anti-A $\beta$ antibody injection to test whether improvements made through combination treatment could be maintained long-term with monotherapy (Figs. 1a, $5 a$ ). In both young and old cohorts, we demonstrate that the reduction in plaque load attained by combination treatment was still present months after the final dose of antibody. Chronic suppression of APP/A $\beta$ prevents the regrowth of amyloid deposits after acute coadministration of anti-A $\beta$ antibody.

\section{Mechanism of combination therapy}

Given the permanence of amyloid aggregates in dox-only mice, plaque clearance by combination therapy likely involves an active process to dismantle preexisting deposits. One possible mechanism for removal of amyloid by combination therapy is activation of microglial phagocytosis. To initiate this process, peripherally administered antibody must reach the brain and bind to aggregated $\mathrm{A} \beta$. However, past work in wild-type mice has shown that $<0.2 \%$ of a parenteral dose of anti-A $\beta$ antibody is found in the brain $6 \mathrm{~h}$ later, and the percentage decreases with time after injection (Levites et al., 2006b). Plaques may shift this equilibrium by offering a "central sponge" of antigen to sequester antibody in the brain. Consistent with this hypothesis, a subset of plaques in 12 of 14 dox plus Ab9 mice were intensely decorated with Ig (Fig. 7a). This was surprising given that these mice received their last dose of Ab9 several months earlier. Nonetheless, additional

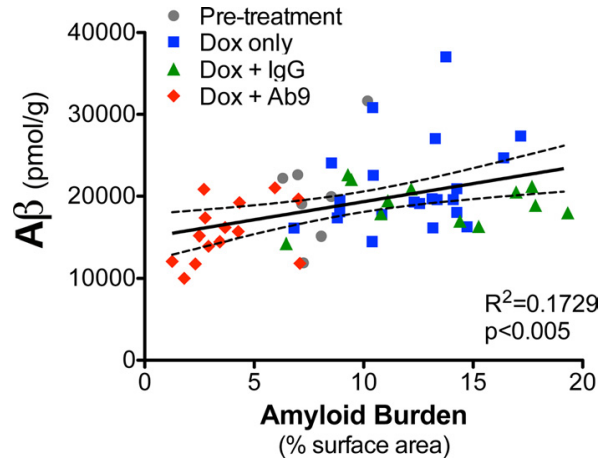

Figure 3. Graph of total $A \beta$ concentration versus amyloid load for animals receiving longterm combination treatment starting at 6 months of age. Graph of $A \beta$ levels measured by ELISA from hemi-forebrain extracts plotted against amyloid percentage surface area measured in the cortex of Campbell-Switzer silver-stained sections confirms a strong correlation between these values.

Table 1. A $\boldsymbol{\beta}$ ELISA data for animals receiving long-term combination treatment starting at 6 months of age

\begin{tabular}{|c|c|c|c|c|}
\hline 12 months & Pretreatment & Dox only & $\lg G+$ dox & $A b 9+$ dox \\
\hline$A \beta x-40$ & $5943 \pm 673$ & $6794 \pm 352$ & $6490 \pm 332$ & $5278 \pm 325^{\dagger}$ \\
\hline$A \beta x-42$ & $14,416 \pm 1773$ & $13,645 \pm 672$ & $13,241 \pm 696$ & $10,381 \pm 693^{* \dagger}$ \\
\hline SDS & $2646 \pm 298$ & $2778 \pm 193$ & $2516 \pm 142$ & $1658 \pm 102^{* t+t \#}$ \\
\hline FA & $17,058 \pm 2023$ & $17,615 \pm 909$ & $17,615 \pm 909$ & $14,000 \pm 895$ \\
\hline Total $A \beta$ & $20,359 \pm 2375$ & $20,401 \pm 925$ & $19,731 \pm 932$ & $15,658 \pm 956^{\dagger}$ \\
\hline
\end{tabular}

Values are expressed as picomoles per gram brain weight \pm SEM.

${ }^{*} p<0.05$ versus pretreatment.

${ }^{\dagger} p<0.05,{ }^{+t+} p<0.001$ versus dox only.

${ }^{\#} p<0.05$ versus $\lg G$ plus dox.

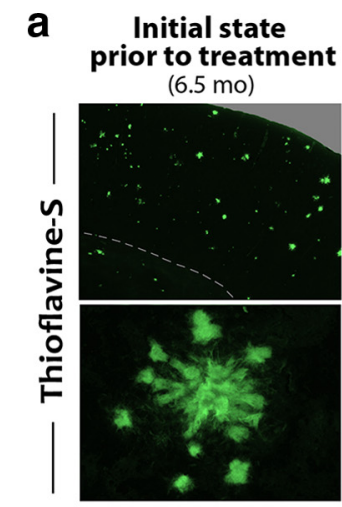

b

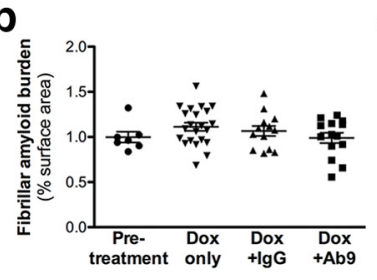

C

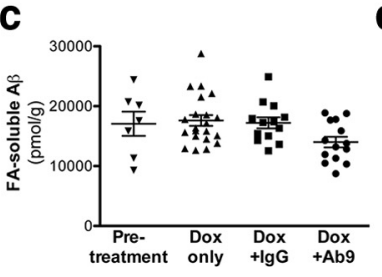

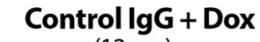
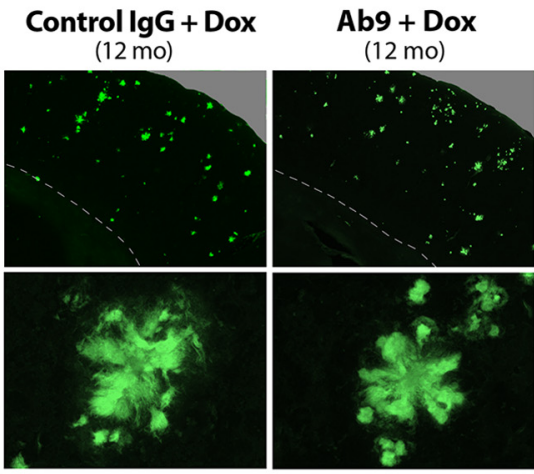

d

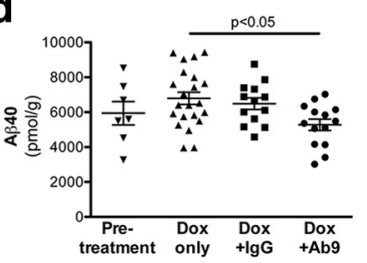

Figure 4. Fibrillar deposits are less amenable to clearance by combination therapy. $\boldsymbol{a}$, The proliferation of thioflavine-S-positive fibrillar plaques was stabilized by suppression of $A P P / A \beta$, but there was no evidence of clearance after addition of Ab9 (top row, $5 \times$; bottom row, $63 \times) . \boldsymbol{b}$, Quantitation of thioflavine-stained sections confirmed that there was no significant change in fibrillar amyloid burden with treatment. c, Biochemical measurements of formic acid-soluble $A \beta$ are generally consistent with the histological measurement of fibrillar amyloid. Differences in formic acid-soluble $A \beta$ (sum of FA-extracted 40 plus 42 ) approached significance when tested by ANOVA ( $p=0.062$ ), driven primarily by the difference between dox-only and dox plus Ab9; direct $t$ test of the two groups yielded $p<0.05$. $\boldsymbol{d}$, Similarly, $A \beta 40$ (sum of SDS plus FA-extracted 40 ) was significantly lower in the dox plus Ab9 group than in dox-only controls. 


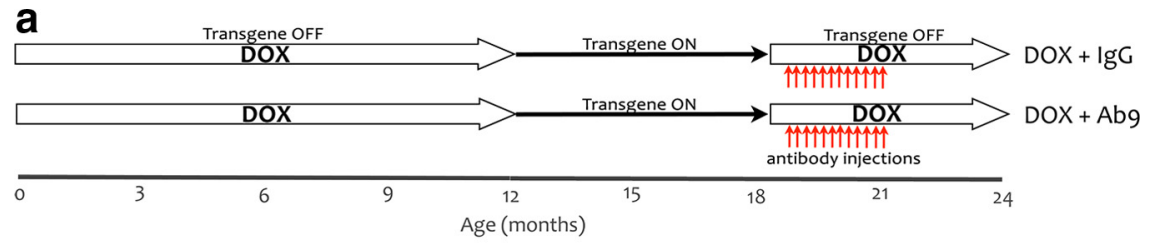

b

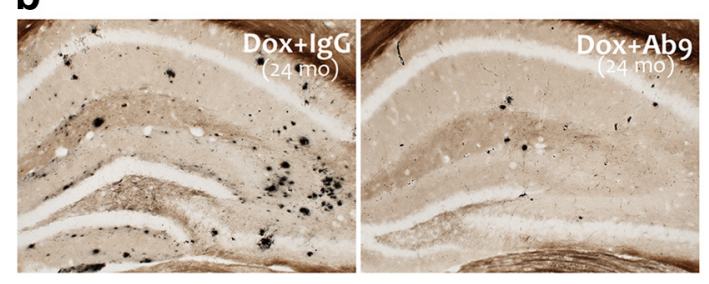

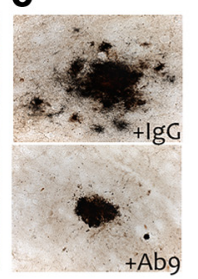

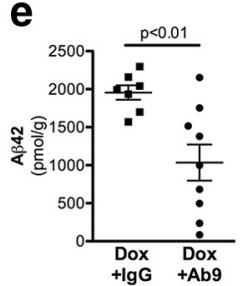

f

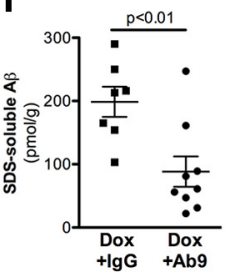

C

d

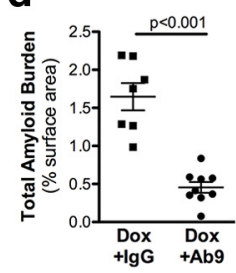

g

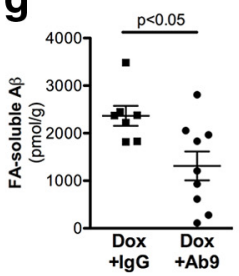

Figure 5. Combination therapy works equally well in aged animals and young adults. $\boldsymbol{a}$, Experimental design. The tet-off system was used to delay transgenic APP expression until 12 months of age. Animals were then taken off dox to start APP overexpression and the experiment proceeded as in the younger cohort: after 6 months of transgenic APP expression, animals were treated with dox for 2 weeks before starting the first of 12 weekly antibody injections with either nonspecific $\lg (n=7)$ or anti-A $\beta$ Ab9 $(n=9)$. Mice remained on dox for 2.5 months after the final injection and were harvested at 24 months of age. $\boldsymbol{b}$, Campbell-Switzer silver staining reveals significantly less amyloid in mice treated with dox plus Ab9 than in age-matched animals given control lgG (10X hippocampal sections). c, Individual plaques from dox plus Ab9-treated mice appear as "naked cores" missing the halo of diffuse amyloid that surrounds larger plaques in control mice $(63 \times)$. $\boldsymbol{d}$, Quantitation of silver-stained sections demonstrates that dox plus Ab9-treated mice have significantly less amyloid than dox plus Ig G controls. $\boldsymbol{e}$ - $\boldsymbol{g}$, ELISA measurement of $A \beta$ levels confirms the histological findings. Significant reductions were found in A $\beta 42$ [sum of SDS plus FA-extracted $42(e)$ ], SDS-soluble $A \beta$ [sum of SDS-extracted 40 plus $42(\boldsymbol{f})$ ], and FA-soluble $A \beta$ [sum of FA-extracted 40 plus $42(\boldsymbol{g})$ ].

Table 2. A $\boldsymbol{\beta}$ ELISA data for animals receiving long-term combination treatment starting at 18 months of age

\begin{tabular}{lcc}
\hline 24 months & $\operatorname{lgG}+$ dox & Ab9 + dox \\
\hline A $\beta x-40$ & $475.8 \pm 36.1$ & $365.9 \pm 92.4^{*}$ \\
A $\beta x-42$ & $1956 \pm 95.3$ & $1034 \pm 237.9^{* *}$ \\
SDS & $198.7 \pm 23.79$ & $88.3 \pm 24.1^{* *}$ \\
FA & $2366 \pm 210.7$ & $1311 \pm 303.6$ \\
Total A $\beta$ & $2418 \pm 134.8$ & $1541 \pm 397.3^{*}$
\end{tabular}

Values are expressed as picomoles per gram brain weight \pm SEM.

${ }^{*} p<0.05,{ }^{* *} p<0.01$ versus $\lg$ G plus dox.

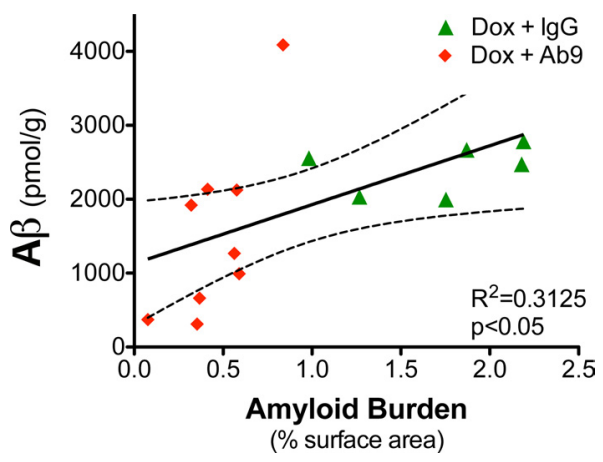

Figure 6. Graph of total $A \beta$ concentration versus amyloid load for animals receiving long-term combination treatment starting at 18 months of age. Graph of $A \beta$ levels measured by ELISA from hemi-forebrain extracts plotted against amyloid percentage surface area measured from the hippocampus of Campbell-Switzer silver-stained sections confirms a significant correlation between these values. analysis demonstrated that the plaquebound antibody was the same isotype as Ab9 (IgG2a), supporting the idea that the originally injected antibody remained bound to the plaques for months after injection (Fig. 7b,c). Combination therapy also prolonged a focused microglial response around deposits (Fig. 8a,b). Relative to amyloid burden (measured by Campbell-Switzer silver stain), the area of CD68 immunostaining [a marker of phagocytic microglia (Bornemann et al., 2001)] was twice as great in combination-treated animals than in animals one-half their age, and $>3.5 \times$ greater than in animals treated only with dox (Fig. $8 d$ ). Surprisingly, the absolute area of CD68 activation, $\sim 1 \%$ of the cortex, remained constant across all conditions, suggesting that the number of CD68+ microglia may be limited and that combination therapy engages cells that are already primed for phagocytosis (Fig. 8c,e).

The effectiveness of combination treatment compared with past studies of Ab9 alone (Levites et al., 2006a,b) suggested that suppressing $\mathrm{A} \beta$ production might allow more Ab9 to reach the brain before becoming inactivated by antigen in the periphery. We tested this hypothesis by administering a brief series of Ab9 injections to two sets of mice, one in which transgenic $\mathrm{APP}$ and $\mathrm{A} \beta$ was suppressed with dox and another in which they continued to be expressed (Fig. 9a). ELISA measurements of plasma $\mathrm{A} \beta$ confirmed that $\mathrm{A} \beta 40$ was $62 \%$ lower $(p<0.05)$ and A $\beta 4271 \%$ lower $(p<0.01)$ in the dox-treated group (Fig. 9b). Harvesting the mice several days after the final Ab9 injection-rather than several months as in our initial experiments-allowed us to compare the extent of antibody penetration into the brain in each condition. Immunostaining for mouse IgG revealed that antibody decoration of amyloid plaques was dramatically increased after Ab9 injection but, to our surprise, was independent of $\mathrm{A} \beta$ synthesis and was seen in mice treated with dox plus Ab9 and Ab9 only (Fig. 9d). Consistent with this finding, Winkler et al. (2010) have detected mouse immunoglobulin at neocortical plaques within hours after a single intravenous dose of anti-A $\beta$ antibody. Intriguingly, we found IgG bound not only to amyloid but also to microglia surrounding the plaques (Fig. 9c). Although we cannot definitively identify the source of the IgG bound to plaques and microglia in acutely treated mice (and the staining was too weak to allow isotype-specific detection), the relative absence of signal in untreated animals suggests that it is likely Ab9.

Animals harvested shortly after the second dose of Ab9 also allowed us to directly test for microglial internalization of $\mathrm{A} \beta$ during treatment. Although microglia are closely associated with amyloid deposits in untreated mice, we rarely found $A \beta$ inside the cells. In contrast, microglia containing $A \beta$ were frequently found in mice treated with Ab9 (Fig. 9e; supplemental Movies $1-3$, available at www.jneurosci.org as supplemental material). As with amyloid opsonization, Ab9-induced enhancement of $A \beta$ uptake was independent of $A \beta$ synthesis. These data suggest that Ab9 administration spurs microglial phagocytosis of amyloid, 
a

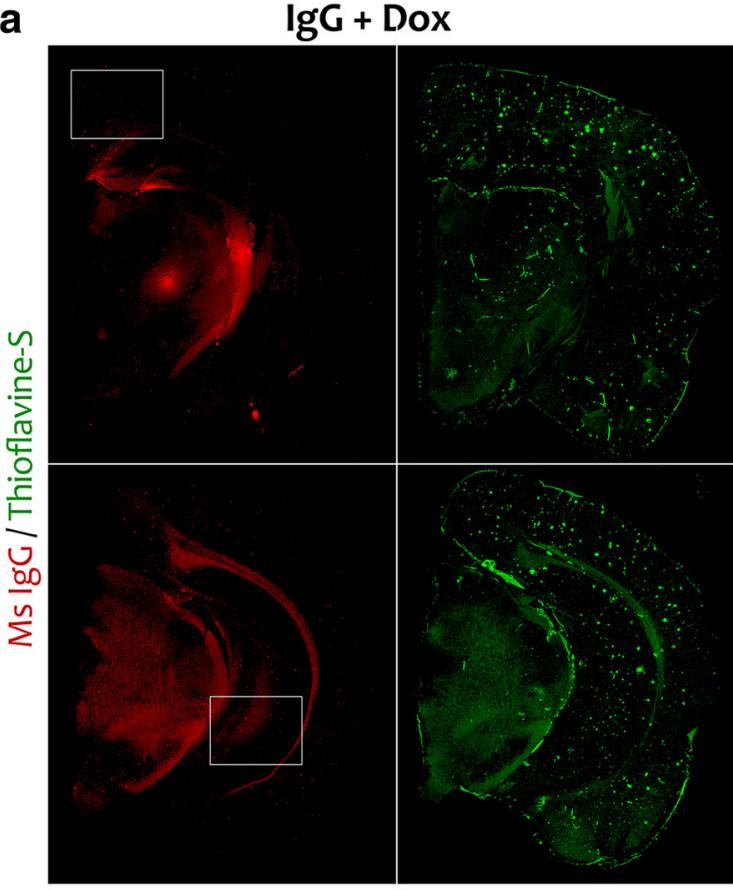

$\mathrm{Abg}+\mathrm{Dox}$

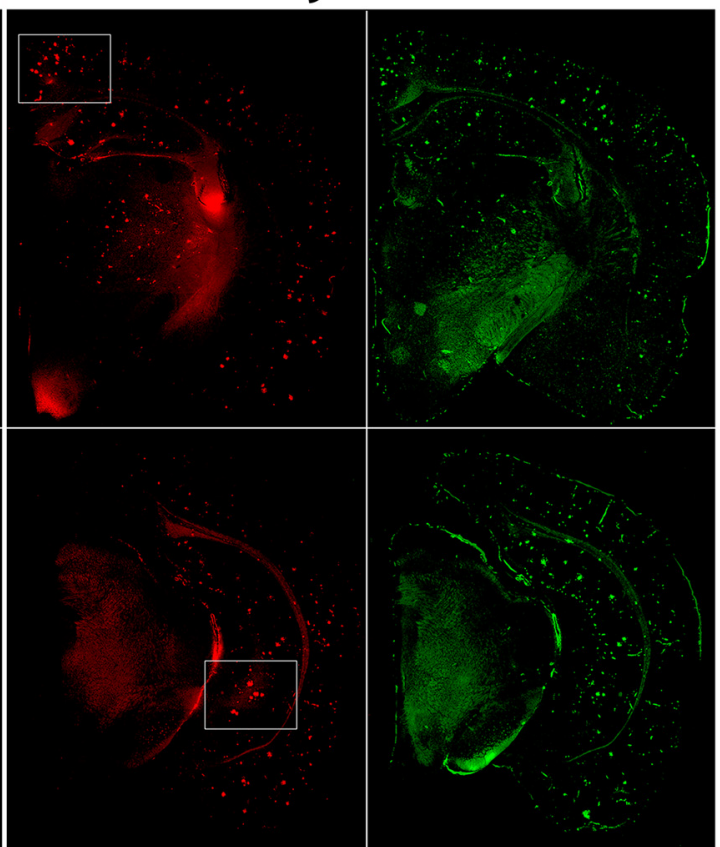

b
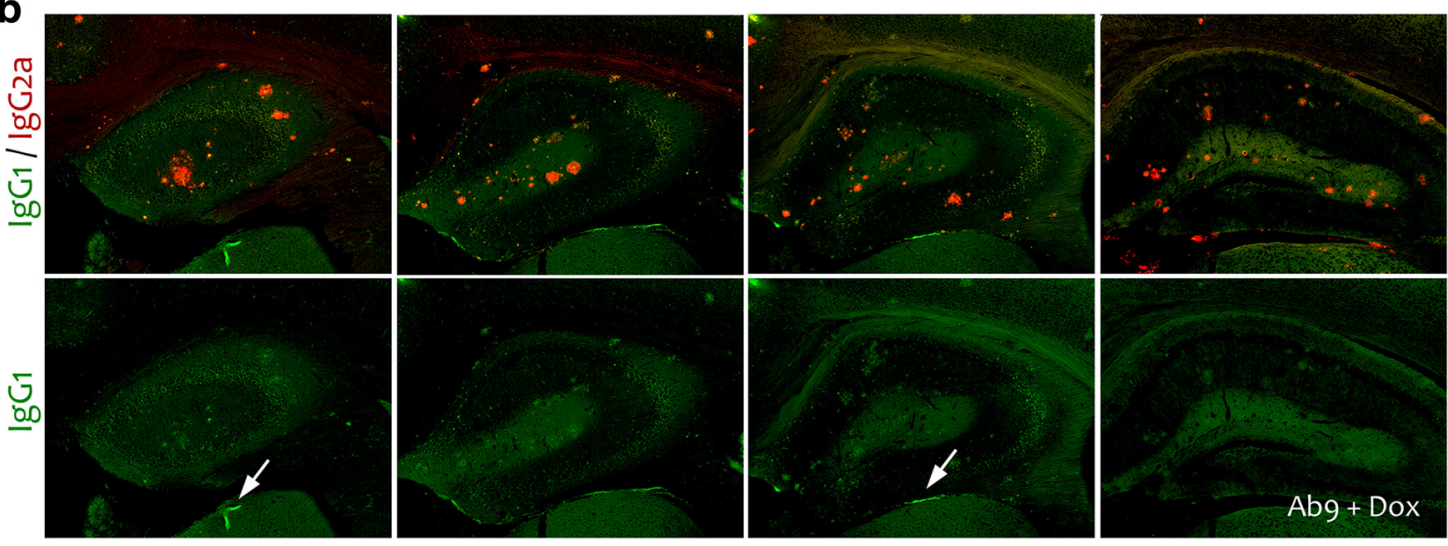

C
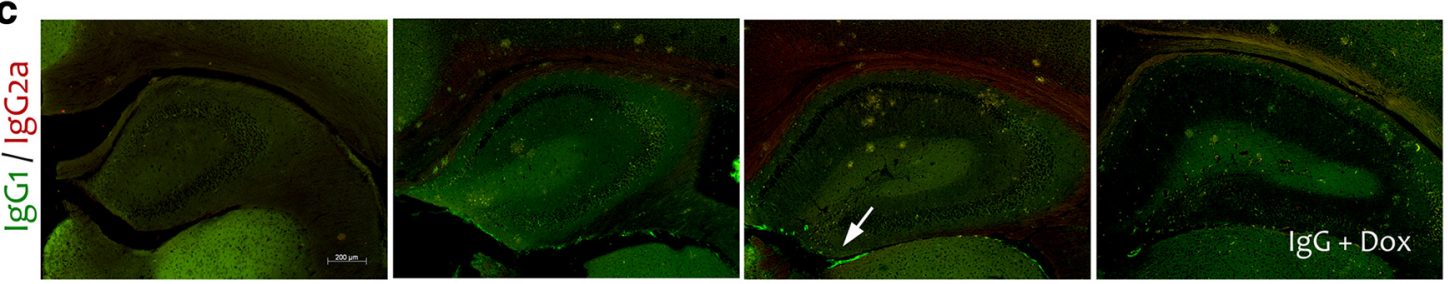

Figure 7. Mouse Ig colocalizes to plaques long after the final injection of Ab9. $\boldsymbol{a}$, Immunostaining for mouse lg $\mathrm{G}$ reveals antibody-decorated plaques nearly 3 months after the final dose of Ab9 (top and bottom rows show different anterior-posterior levels of the brain at $1 \times$ magnification). Amyloid-associated antibody is found only in mice treated with Ab9 and decorates only a subset of plaques. The boxes highlight similar areas in dox plus IgG and dox plus Ab9 sections to facilitate comparison. $\boldsymbol{b}$, Plaques in dox plus Ab9-treated mice were isotyped by immunostaining with subtype-specific secondaries. Plaques were strongly positive for lgG2a — the same isotype as Ab9 (red, top row, $5 \times$ ) — but negative for lgG1 (green, top and bottom rows, $5 \times$ ). Instead, IgG1 signal can be found associated with blood vessels in the thalamus and meninges ventral to the hippocampus (arrows, bottom row), indicating that the absence of signal at plaques is not attributable to failure of the immunostain. $c$, No staining above background for either isotype is found at deposits in mice administered dox plus control lgG (as in $\boldsymbol{b}$, the arrow indicates lgG1-positive blood vessel; $5 \times$ ).

but that only when additional production of $\mathrm{A} \beta$ is arrested can it make an impact on amyloid burden.

\section{Caution in the potential use of combination therapy}

Recent studies in multiple lines of APP transgenic mice have shown that repeated injections with anti-A $\beta$ antibodies can increase vascular amyloid and microhemorrhage (Thakker et al., 2009) (but see Schroeter et al., 2008). We tested whether combination therapy impacted either of these conditions in our chronically treated animals. Unlike past studies of monotherapy with anti-A $\beta$ antibody, mice receiving dox plus Ab9 showed no change in the number of cortical penetrating vessels with perivascular amyloid compared with dox plus IgG controls (Fig. 10a,b). However, the frequency of microhemorrhage but not the severity of individual bleeds was significantly increased by Ab9 (frequency: dox plus Ab9, $0.71 \pm 0.16$, vs dox plus IgG, $0.26 \pm 0.054$ bleeds/section; $p<0.05, t$ test with Welch's correction; severity: dox plus Ab9, $1.231 \pm 0.057$, vs dox plus 


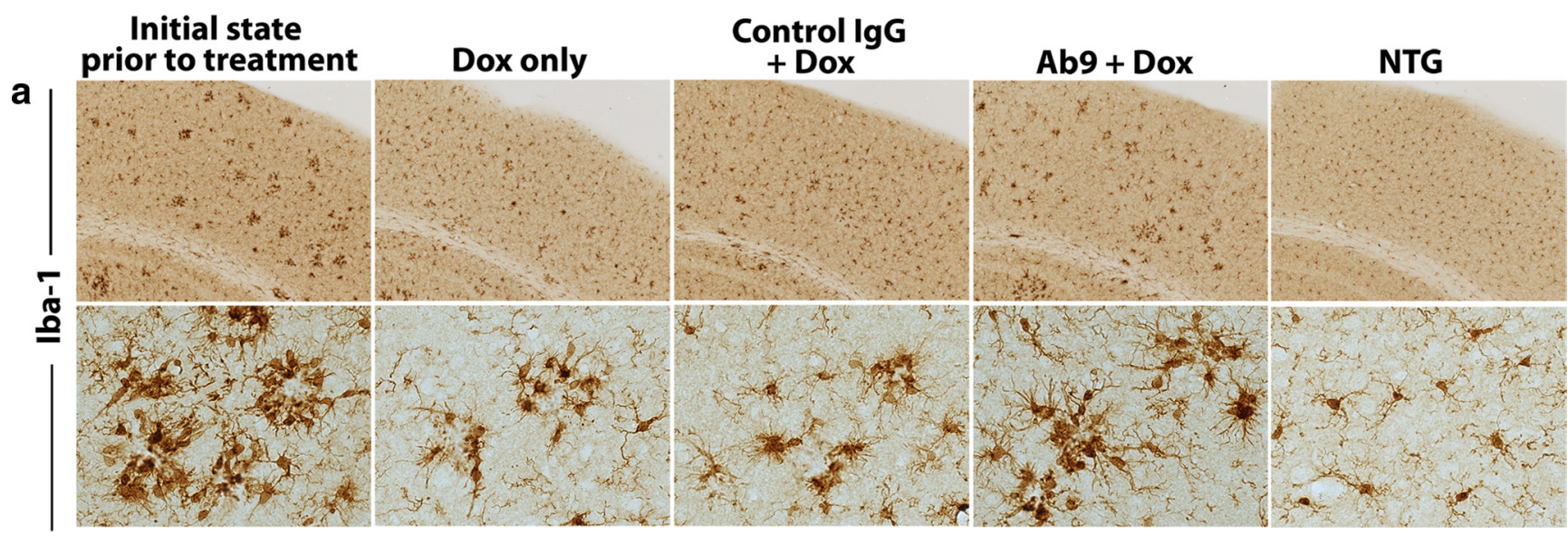

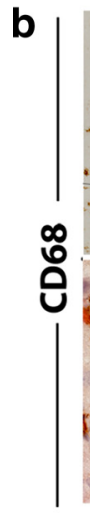

C
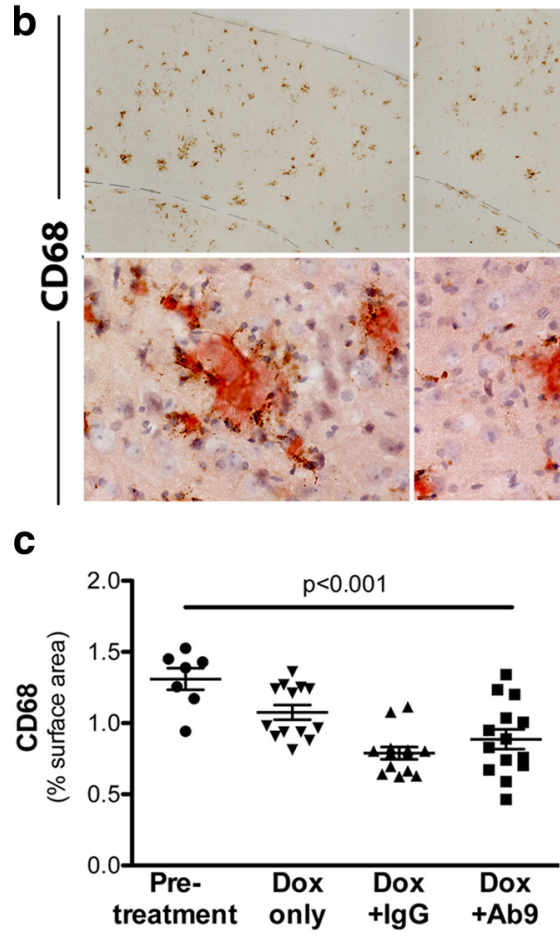

treatment only $+\lg G \quad+$ Ab9 d
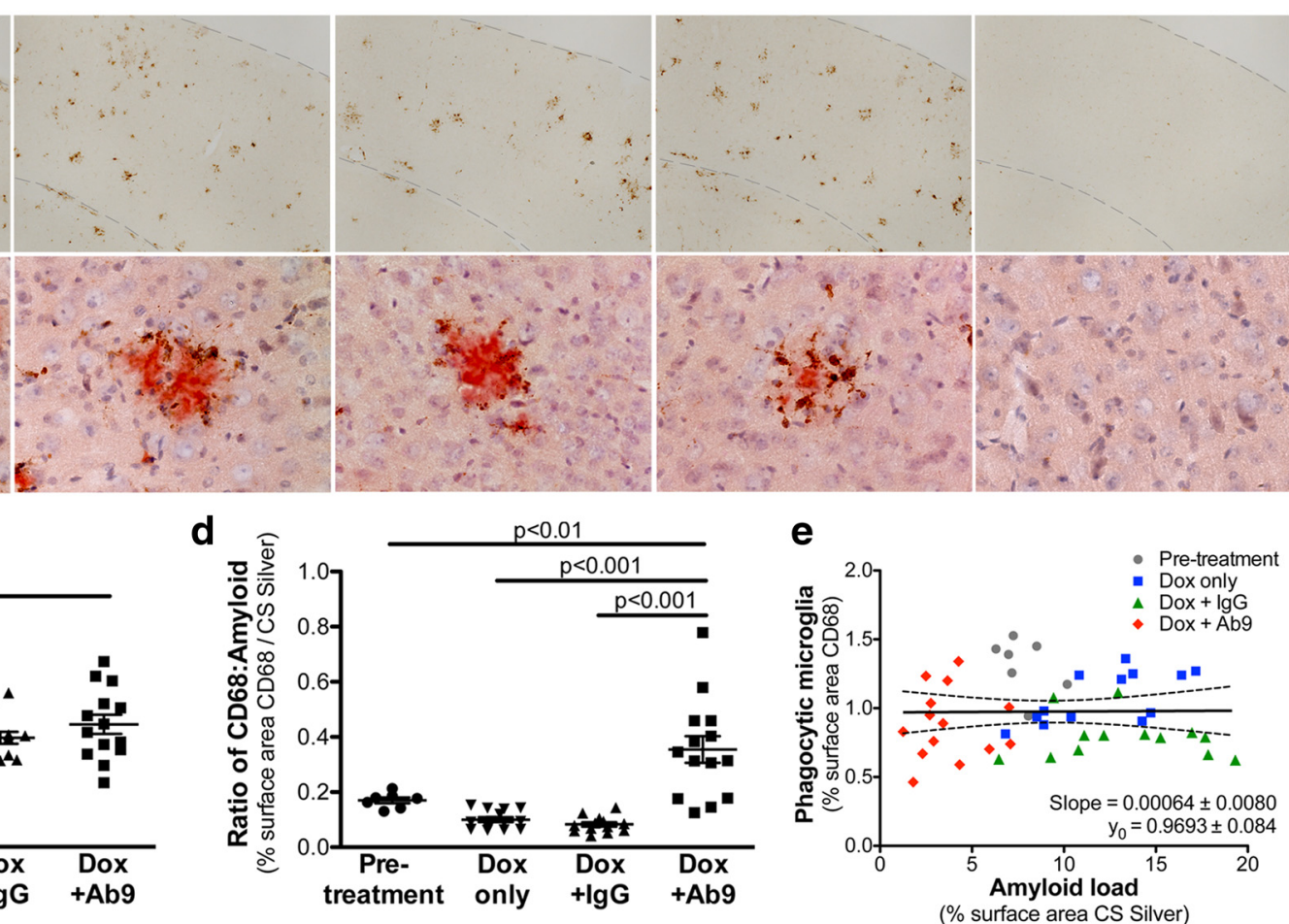

Figure 8. Combination therapy focuses the microglial response to amyloid. $\boldsymbol{a}$, Immunostaining with Iba-1, a generic microglial marker, shows a dense gathering of microglia around amyloid cores in untreated mice. In the absence of continued amyloid deposition (dox-only and dox plus lgG), the concentration of microglia becomes less pronounced. In comparison, coadministration of Ab9 maintains the presence of microglia around amyloid foci (top row, $5 \times$; bottom row, $63 \times$ ). Nontransgenic animals show basal Iba- 1 staining in the absence of pathology. $\boldsymbol{b}$, Immunostaining with CD68, a marker of microglial lysosomes, confirmed that the cells concentrated around plaques are activated and potentially phagocytic (top row, $5 \times$ ). Counterstaining with Congo red highlights the disparity between the size of plaques in each condition and the number of $C D 68$-positive microglia surrounding them (bottom row, $63 \times$ ). $c$, Quantitation of $C D 68$ immunostaining indicates there is no difference in the area occupied by $\mathrm{CD} 68+$ microglia between dox plus Ab9-treated mice and age-matched controls. $\boldsymbol{d}$, When considered in relation to the plaque burden carried by each treatment group, the dox plus Ab9-treated mice have significantly more CD68+ microglia per unit amyloid than any of the control groups (measured as CD68 area vs amyloid burden from Campbell-Switzer silver staining). Significant comparisons are shown for dox plus Ab9; other significant comparisons were as follows: microglial activation: pretreatment versus dox plus lgG ( $p<$ $0.001)$, dox only versus dox plus lg $(p<0.01)$. , The area occupied by phagocytic CD68 + microglia is relatively constant across amyloid burden and treatment condition, consistent with the idea that combination therapy focuses a fixed microglial response around less remaining amyloid. There is no correlation between percentage CD68 area and amyloid load measured by Campbell-Switzer silver stain [slope of the linear regression is not significantly different from $0\left(p=0.94, R^{2}=0.0001\right)$; dashed lines indicate the $95 \%$ confidence interval].

IgG, $1.107 \pm 0.060 ; p=$ NS) (Fig. 10c). These findings confirm that therapeutic use of anti-A $\beta$ antibody comes with some risk. However, $\mathrm{A} \beta$ suppression to maintain improvements made during combination treatment may allow greater flexibility in the timing and dosage of antibody administration so that microhemorrhage can be minimized.

\section{Discussion}

In light of recent imaging data showing that many patients develop amyloid deposits long before diagnosis (Rabinovici and Jagust, 2009), future treatments for AD may be most effective if they can clear preexisting plaques (Thakker et al., 2009; Rinne et al., 2010). Here, we demonstrate significant clearance of deposited amyloid by combining two complementary approaches, one based on arresting additional production of $A \beta$ and another on sequestering peptide after it is released. Both approaches have been shown to slow or stop the progression of amyloid pathology in transgenic mice, but neither alone reverses deposition (see below). Here, we show that, used in combination, these treatments result in lower amyloid burden than was present before treatment. Importantly, both therapeutic approaches used in our 
study are currently in human clinical trials (clinicaltrials.gov). Although broadspectrum $\gamma$-secretase inhibitors may now be viewed with caution after the recent discontinuation of trials for semagacestat (LY-450139), the development of new APP-specific $\gamma$-secretase inhibitors (Mayer et al., 2008; Basi et al., 2010) offers renewed hope for treatment strategies based on limiting $\mathrm{A} \beta$ production and the possibility of combining these drugs with antibody-based therapies.

As we have previously shown with the tet-off APP mice, therapeutic intervention to stop the production of APP/A $\beta$ slows amyloid accumulation but does not remove plaques formed before treatment (Jankowsky et al., 2005). Our current results confirm this conclusion. Two recent studies demonstrate the same outcome after chronic treatment with $\gamma$-secretase inhibitors (Abramowski et al., 2008; Garcia-Alloza et al., 2009). In contrast, anti-A $\beta$ antibody treatment rapidly clears preexisting plaques in transgenic mice, but only when administered directly into the brain (Bacskai et al., 2001, 2002; Lombardo et al., 2003; Wilcock et al., 2003, 2004a; Oddo et al., 2004; Brendza et al., 2005; Maeda et al., 2007; Thakker et al., 2009). Although the term "clearance" is frequently used when describing the impact of peripherally administered antibodies, the effect in most mouse models is likely the same as with $\mathrm{A} \beta$ suppression: slowing or arrest of amyloid accumulation. Few studies have compared $\mathrm{A} \beta$ levels or amyloid load after peripheral antibody transfer to what was present when treatment started. Instead, most compare the difference between treated and untreated animals of the same age (Bard et al., 2000; DeMattos et al., 2001; Pfeifer et al., 2002; Bussière et al., 2004; Wilcock et al., 2004b, 2006; Buttini et al., 2005; Hartman et al., 2005; Levites et al., 2006a; Brody and Holtzman, 2008). In many cases, studies have relied on previous characterization of the transgenic line to estimate the amyloid load present at the outset of treatment. However, because many factors can influence the onset of amyloid formation, including gender (Wang et al., 2003; Hirata-Fukae et al., 2008), strain background (Lehman et al., 2003), diet (Howland et al., 1998; Levin-Allerhand et al., 2002; Praticò et al., 2002; Bayer et al., 2003; Lim et al., 2005; Patel et al., 2005; Oksman et al., 2006), and housing conditions (Jankowsky et al., 2003; Lazarov et al., 2005; Cracchiolo et al., 2007), it is unwise to assume that a transgenic line will perform identically in all studies. Without a
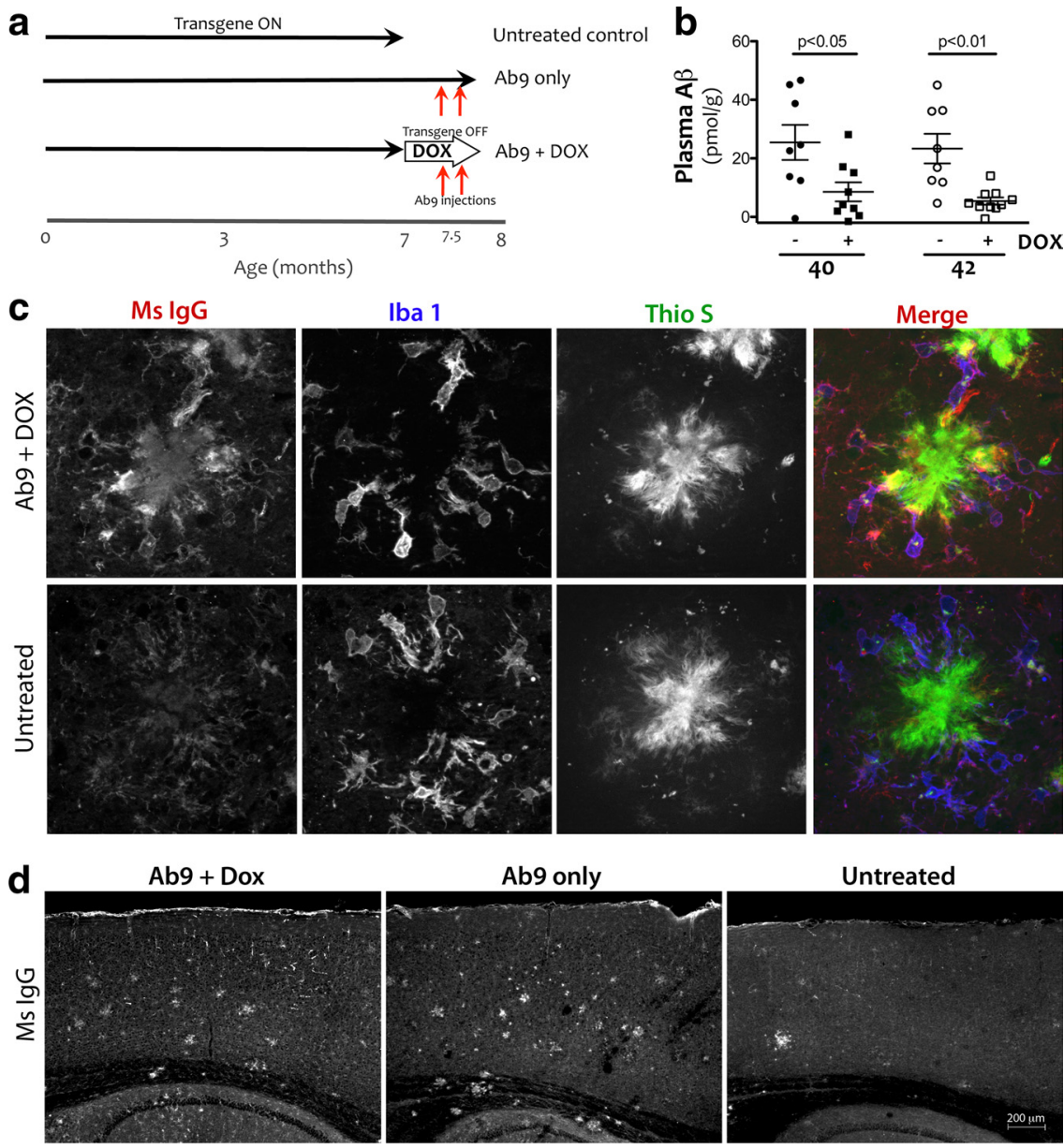

e
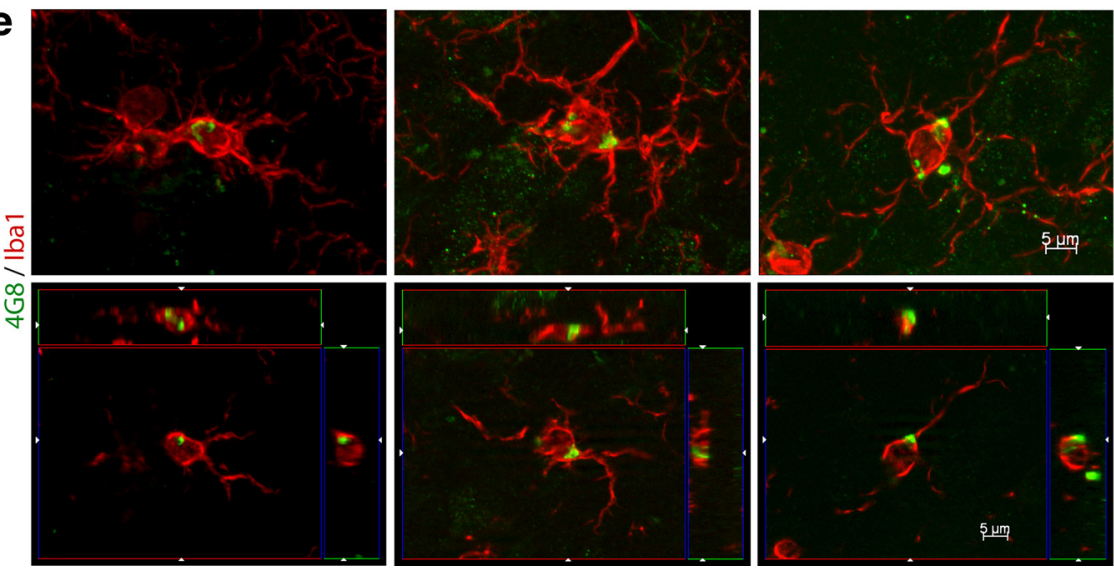

Figure 9. Passive immunization promotes microglial internalization of $A \beta$ aggregates. $\boldsymbol{a}$, Short-term treatment was used to investigate the mechanism of plaque clearance in combination therapy. At 7 months of age, animals were divided into two groups, one placed on dox chow $(n=6)$ and the other left unmedicated $(n=3)$. Two weeks later, both groups received the first of two Ab9 injections. Mice were harvested $3 \mathrm{~d}$ after the second injection. Untreated mice served as controls $(n=2)$. $\boldsymbol{b}$, Plasma samples taken immediately before the first Ab9 injection confirm that the concentration of transgene-derived $A \beta$ was significantly reduced by dox. Graph includes mice receiving unlabeled $(n=9)$ or biotinylated $\operatorname{Ab9}(n=9$; not used further). c, Triple labeling with thioflavine for fibrillar amyloid (green) and immunofluorescence for microglia (Iba1, blue) and mouse pan-lgG (red) demonstrates that Ab9 treatment led to $\lg G$ binding of both plaques and microglia $(63 \times)$. $\boldsymbol{d}$, Plaque decoration with mouse lgG was dramatically enhanced after Ab9 injection independent of circulating $A \beta$ levels $(5 \times)$.e, Double immunofluorescence for microglia (Iba-1, red) and A $\beta(4 G 8$, green) reveals that $A b 9$ treatment stimulated microglial engulfment of $A \beta$ aggregates (top row, multiple image projection; bottom row, single optical section; $63 \times)$. Microglia were often found in close apposition to $A \beta$ in untreated mice but often contained $A \beta$ in mice treated with $A b 9$. As with the increase in plaque-bound IgG, the stimulation of microglial $A \beta$ internalization was independent of APP/A $\beta$ expression. Three-dimensional rotations of these cells are provided as movie files in supplemental information (available at www.jneurosci.org as supplemental material). 

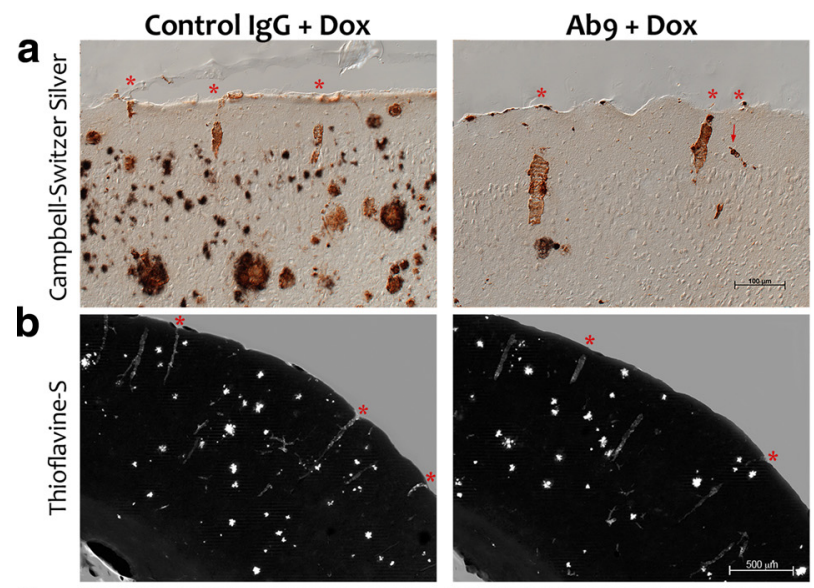

C
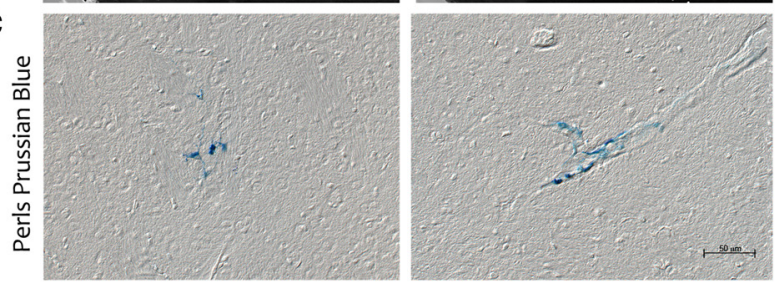

Figure 10. Vascular amyloid is unchanged but microhemorrhage frequency is increased by combination therapy. $\boldsymbol{a}, \boldsymbol{b}$, Campbell-Switzer silver $(\boldsymbol{a}, 10 \times \mathrm{DIC})$ and thioflavine-S staining $(\boldsymbol{b}, 5 \times$ fluorescence $)$ were used to assess the frequency of blood vessels harboring amyloid deposits in cortical layer 1. No significant difference was seen in the number of amyloid-positive vessels per section between animals receiving control lgG plus dox and those given Ab9 plus dox. c, Perls Prussian blue histology revealed an increased frequency but no change in severity of cerebral microhemorrhage $(20 \times \mathrm{DIC})$.

knowledge of the pretreatment burden, it is difficult to demonstrate true clearance as opposed to attenuation of deposition. Recognizing this distinction, recent phase 2 clinical trials with bapineuzumab incorporated ${ }^{11} \mathrm{C}$-labeled Pittsburgh compound $\mathrm{B}$ binding to measure amyloid load both before and during treatment to reveal a significant $8.5 \%$ reduction in the immunized patients (Rinne et al., 2010). This study demonstrated that, with prolonged treatment (18 months to effect in the phase 2 trial), passive antibody treatment appears capable of modestly reducing amyloid levels, although given the relatively small number of subjects additional confirmatory studies are needed. Our current findings suggest that a combination approach could accelerate and enhance this effect.

As with passive immunization, several studies of active immunization against $A \beta$ have also claimed to show amyloid clearance either without measuring pretreatment levels or when the evidence better supports a more cautious interpretation. The first immunotherapy study to be published for Alzheimer's disease stated that immunization of 11-month-old mice with $\mathrm{A} \beta 42$ resulted in several mice with "fewer diffuse and mature amyloid- $\beta$ deposits at 15 and 18 months, suggesting that the treatment had resulted in the clearance of preexisting amyloid- $\beta$ deposits"; however, no statistical comparison to the pretreatment group was performed. When $A \beta$ concentrations were measured by ELISA, they were identical in the immunized mice and in those harvested before treatment (Schenk et al., 1999), making it difficult to conclude that preexisting $\mathrm{A} \beta$ deposits were cleared. Thus, this finding like many others is more consistent with treatment preventing additional deposition than clearing antecedent deposits. This interpretation might also be applied to the results of the AN-1792 clinical trials, in which low levels of amyloid in several treated patients were taken to suggest evidence for plaque clearance (Nicoll et al., 2003, 2006; Holmes et al., 2008). Based on
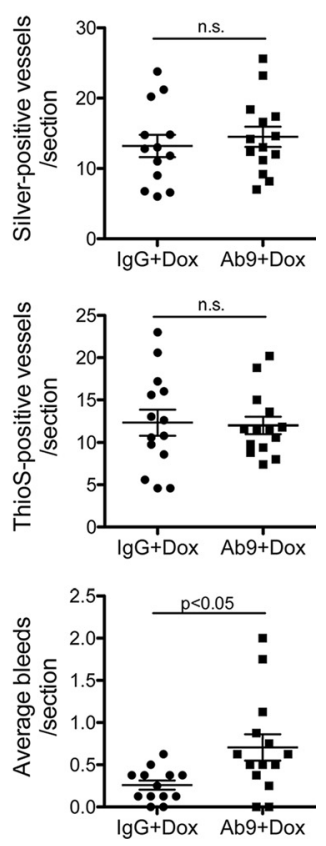

decades of clinicopathological studies, it was reasonable to assume that most of the study participants with mild-to-moderate $\mathrm{AD}$ have amyloid, and to be fair, when these studies began there was no way to evaluate plaque burden before death. But in the absence of data showing the presence and extent of pathology before immunization, it would be safer to conclude that treatment prevented pathology from worsening rather than reversing pathology that may not have existed. Admittedly, one conundrum in this interpretation is the appearance in several immunized patients of cortical patches lacking amyloid immediately adjacent to areas with considerable plaque accumulation (Nicoll et al., 2003; Boche et al., 2010). However, as the appearance of meningioencephalitis in several of the immunized patients dramatically revealed (Orgogozo et al., 2003; Bayer et al., 2005), active immunization invokes responses beyond antibody production and any clearance that may have occurred in these patients could have resulted from antibody-independent mechanisms.

Our impetus for marrying passive immunization with $\mathrm{A} \beta$ suppression was straightforward: draining a flood is easier once the water stops. We had initially hypothesized that limiting the amount of $\mathrm{A} \beta$ in the periphery would allow more free antibody to reach the brain. Our data suggest that anti-A $\beta$ antibody $\mathrm{Ab} 9$ reaches the brain and colocalizes with both amyloid and microglia, independent of transgenic APP expression. However, even when the transgene is active, the tet-off APP mice produce only moderate levels of plasma $\mathrm{A} \beta$; models with higher levels of peripheral $\mathrm{A} \beta$ might show a greater influence on how much free antibody reaches the CNS. Past studies revealed a critical role for microglia in determining plaque burden, with the suggestion that these cells phagocytose $A \beta$ aggregates during normal disease progression (D'Andrea et al., 2004; Simard et al., 2006; El Khoury et al., 2007; Kellner et al., 2009) and become specifically activated in response to anti-A $\beta$ immunotherapy (Bard et al., 2000; Wilcock et al., 2003, 2004a,b; Koenigsknecht-Talboo et al., 2008). Our findings further support a role for microglial phagocytosis in antibody-driven plaque clearance and suggest that the capacity of microglial clearance is insufficient to overcome the continued accumulation of amyloid in APP transgenic mice. The efficacy of combination therapy lies in its ability to stave off additional aggregation while microglia dispose of earlier deposits. We expect that the near-complete $\mathrm{A} \beta$ suppression attained here using a genetic switch may only be required for passive immunization to overcome the exaggerated $\mathrm{A} \beta$ production of our mouse models. Successful treatment may be achieved in human patients with less efficient suppression. Our findings suggest that reducing $\mathrm{A} \beta$ release by any amount will improve amyloid clearance by passive immunization.

In contrast to our findings of improved amyloid clearance by combination therapy, a previous study by Wilcock et al. (2007) found no improvement by combining immunization with a $\gamma$-secretase modulator over monotherapy alone. Although both active immunization against $\mathrm{A} \beta 42$ and nonsteroidal antiinflammatory treatment using the modified flurbiprofen derivative 3-[4-(2- 
fluoro- $\alpha$-methyl-[1,1'-biphenyl]-4-acetyloxy)-3-methoxyphenyl]2-propenoic acid 4-nitrooxy butyl ester (NCX-2216) diminished amyloid accumulation compared with untreated controls, their combination provided no benefit over either alone. However, toxicity of NCX-2216 killed many of their combination-treated mice, leaving only three animals for analysis. In addition, the use of active as opposed to passive immunization resulted in highly variable anti-A $\beta$ antibody titers, which may have increased variability in treatment outcomes. Additional study is needed to determine whether larger treatment groups with multivariate analysis of amyloid load against antibody titer might yield a different conclusion.

One caveat in interpreting our findings is the fact that we did not directly test the effect of Ab9 alone in our tet-off APP mice. In retrospect, we would have done well to include this control; however, when designing the study, we believed the question had already been answered by our past work in mice with even lower starting levels of aggregated $A \beta$. Our original study of $A b 9$ passive immunization found only modest attenuation of plaque burden in Tg2576 and CRND8 mice that began Ab9 treatment with much less amyloid than the tet-off APP mice used here (Levites et al., 2006a). In these studies, the effect was consistent with prevention of accumulation rather than clearance of preexisting plaques. In mice with amyloid loads comparable with those studied here, direct intracranial injection of $\mathrm{Ab} 9$ was required to demonstrate any effect on $\mathrm{A} \beta$, and then only diffuse plaques were affected. Indeed, both the epitope specificity of Ab9 (A $\beta 1-16)$ and its isotype (IgG2a) may have contributed to this outcome, and the possibility exists that other antibodies may function through distinct mechanisms or have different capabilities for removing preexisting amyloid. However, based on these previous studies showing only attenuation of deposition after peripheral Ab9 treatment versus the unambiguous evidence of amyloid reduction provided here, we think it is reasonable to infer that combination therapy is needed for clearance with this antibody.

We further show that plaque reductions attained through combination treatment can be maintained long afterward with monotherapy. All of the mice receiving long-term treatment with dox plus Ab9 were harvested 2.5 months after their final antibody injection. During that time, the animals continued on dox to limit transgenic $\mathrm{APP} / \mathrm{A} \beta$ synthesis. As shown in previous studies with the tet-off APP mice, $\gamma$-secretase inhibitors, and passive anti- $\mathrm{A} \beta$ immunization, reducing $\mathrm{A} \beta$ concentration can maintain amyloid levels indefinitely at the level present when treatment started (Jankowsky et al., 2005; Abramowski et al., 2008; Garcia-Alloza et al., 2009; Karlnoski et al., 2009). Here, we test long-term treatment with dox as a "maintenance dose" to preserve improvements made during a short-term "loading dose" of combination treatment. Given the potential side effects associated with use of passive antibody transfer in mice (Pfeifer et al., 2002; Wilcock et al., 2004c; Lee et al., 2005; Racke et al., 2005), and in humans (Salloway et al., 2009), it may be important to limit the duration of antibody exposure and preserve recovery without continued risk. Our results demonstrate that chronic $A \beta$ suppression meets this need.

Additional study is needed to determine whether the outcome of combination treatment could be improved by optimizing our dosing strategy. Several groups are testing ways to increase the brain penetrance of peripherally delivered antibody, including polyamine modification or ultrasonic disruption of the bloodbrain barrier (Poduslo et al., 2007; Choi et al., 2008; Raymond et al., 2008). We could also simply intervene earlier. Dox plus Ab9 intervention at both 6 and 18 months yielded an equivalent 72\% reduction in amyloid load compared with dox plus IgG, but be- cause the 18 month mice started treatment with less amyloid, they ended with almost none. The ending levels of amyloid in the two cohorts likely also reflect the greater abundance of cored plaques in the 6-month-old mice at the outset of treatment. The compact structure of fibrillar deposits may leave them less vulnerable to attack; alternatively, as the innermost core beneath a layer of diffuse amyloid that must be cleared first, they may simply require longer to clear than was tested here.

A critical question to be addressed in future is whether plaque clearance is necessary for maximum functional recovery. Our current experiments could not assess behavior because of the animals' mixed hybrid background and persistent hyperactivity (Jankowsky et al., 2005); these mice were bred for pathology rather than performance. What role plaques play in cognitive decline remains a topic of debate. Certainly, plaques have been shown to cause both physical damage such as neuritic swelling, swerving, and breakage (Le et al., 2001; D'Amore et al., 2003; Lombardo et al., 2003; Tsai et al., 2004; Meyer-Luehmann et al., 2008) and functional deficits such as desynchronized transmission, neuronal hyperactivity, and calcium dysregulation (Stern et al., 2004; Busche et al., 2008; Kuchibhotla et al., 2008). Thus, it will be critical to understand whether their clearance is required for optimum functional recovery and whether it should be a target for future treatment. Our study suggests that combination therapy may be a valuable tool in making these assessments.

\section{References}

Abramowski D, Wiederhold KH, Furrer U, Jaton AL, Neuenschwander A, Runser MJ, Danner S, Reichwald J, Ammaturo D, Staab D, Stoeckli M, Rueeger H, Neumann U, Staufenbiel M (2008) Dynamics of A $\beta$ turnover and deposition in different $\beta$-amyloid precursor protein transgenic mouse models following $\gamma$-secretase inhibition. J Pharmacol Exp Ther 327:411-424.

Bacskai BJ, Kajdasz ST, Christie RH, Carter C, Games D, Seubert P, Schenk D, Hyman BT (2001) Imaging of amyloid- $\beta$ deposits in brains of living mice permits direct observation of clearance of plaques with immunotherapy. Nat Med 7:369-372.

Bacskai BJ, Kajdasz ST, McLellan ME, Games D, Seubert P, Schenk D, Hyman BT (2002) Non-Fc-mediated mechanisms are involved in clearance of amyloid- $\beta$ in vivo by immunotherapy. J Neurosci 22:7873-7878.

Bard F, Cannon C, Barbour R, Burke RL, Games D, Grajeda H, Guido T, Hu K, Huang J, Johnson-Wood K, Khan K, Kholodenko D, Lee M, Lieberburg I, Motter R, Nguyen M, Soriano F, Vasquez N, Weiss K, Welch B, et al. (2000) Peripherally administered antibodies against amyloid $\beta$-peptide enter the central nervous system and reduce pathology in a mouse model of Alzheimer disease. Nat Med 6:916-919.

Basi GS, Hemphill S, Brigham EF, Liao A, Aubele DL, Baker J, Barbour R, Bova M, Chen XH, Dappen MS, Eichenbaum T, Goldbach E, Hawkinson J, LawlerHerbold R, Hu K, Hui T, Jagodzinski JJ, Keim PS, Kholodenko D, Latimer LH, et al. (2010) Amyloid precursor protein selective $\gamma$-secretase inhibitors for treatment of Alzheimer's disease. Alzheimers Res Ther 2:36.

Bayer AJ, Bullock R, Jones RW, Wilkinson D, Paterson KR, Jenkins L, Millais SB, Donoghue S (2005) Evaluation of the safety and immunogenicity of synthetic A $\beta 42$ (AN1792) in patients with AD. Neurology 64:94-101.

Bayer TA, Schäfer S, Simons A, Kemmling A, Kamer T, Tepest R, Eckert A, Schüssel K, Eikenberg O, Sturchler-Pierrat C, Abramowski D, Staufenbiel M, Multhaup G (2003) Dietary Cu stabilizes brain superoxide dismutase 1 activity and reduces amyloid $\mathrm{A} \beta$ production in APP23 transgenic mice. Proc Natl Acad Sci U S A 100:14187-14192.

Boche D, Denham N, Holmes C, Nicoll JA (2010) Neuropathology after active $A \beta 42$ immunotherapy: implications for Alzheimer's disease pathogenesis. Acta Neuropathol 120:369-384.

Bornemann KD, Wiederhold KH, Pauli C, Ermini F, Stalder M, Schnell L, Sommer B, Jucker M, Staufenbiel M (2001) A $\beta$-induced inflammatory processes in microglia cells of APP23 transgenic mice. Am J Pathol 158:63-73.

Brendza RP, Bacskai BJ, Cirrito JR, Simmons KA, Skoch JM, Klunk WE, Mathis CA, Bales KR, Paul SM, Hyman BT, Holtzman DM (2005) Anti-A $\beta$ antibody treatment promotes the rapid recovery of amyloid- 
associated neuritic dystrophy in PDAPP transgenic mice. J Clin Invest 115:428-433.

Brody DL, Holtzman DM (2008) Active and passive immunotherapy for neurodegenerative disorders. Annu Rev Neurosci 31:175-193.

Busche MA, Eichhoff G, Adelsberger H, Abramowski D, Wiederhold KH, Haass C, Staufenbiel M, Konnerth A, Garaschuk O (2008) Clusters of hyperactive neurons near amyloid plaques in a mouse model of Alzheimer's disease. Science 321:1686-1689.

Bussière T, Bard F, Barbour R, Grajeda H, Guido T, Khan K, Schenk D, Games D, Seubert P, Buttini M (2004) Morphological characterization of Thioflavin-S-positive amyloid plaques in transgenic Alzheimer mice and effect of passive $A \beta$ immunotherapy on their clearance. Am J Pathol 165:987-995.

Buttini M, Masliah E, Barbour R, Grajeda H, Motter R, Johnson-Wood K, Khan K, Seubert P, Freedman S, Schenk D, Games D (2005) $\beta$-Amyloid immunotherapy prevents synaptic degeneration in a mouse model of Alzheimer's disease. J Neurosci 25:9096-9101.

Choi JJ, Wang S, Brown TR, Small SA, Duff KE, Konofagou EE (2008) Noninvasive and transient blood-brain barrier opening in the hippocampus of Alzheimer's double transgenic mice using focused ultrasound. Ultrason Imaging 30:189-200.

Cracchiolo JR, Mori T, Nazian SJ, Tan J, Potter H, Arendash GW (2007) Enhanced cognitive activity — over and above social or physical activity —is required to protect Alzheimer's mice against cognitive impairment, reduce $\mathrm{A} \beta$ deposition, and increase synaptic immunoreactivity. Neurobiol Learn Mem 88:277-294.

D’Amore JD, Kajdasz ST, McLellan ME, Bacskai BJ, Stern EA, Hyman BT (2003) In vivo multiphoton imaging of a transgenic mouse model of Alzheimer disease reveals marked thioflavine-S-associated alterations in neurite trajectories. J Neuropathol Exp Neurol 62:137-145.

D'Andrea MR, Cole GM, Ard MD (2004) The microglial phagocytic role with specific plaque types in the Alzheimer disease brain. Neurobiol Aging 25:675-683.

DeMattos RB, Bales KR, Cummins DJ, Dodart JC, Paul SM, Holtzman DM (2001) Peripheral anti-A $\beta$ antibody alters CNS and plasma $A \beta$ clearance and decreases brain $A \beta$ burden in a mouse model of Alzheimer's disease. Proc Natl Acad Sci U S A 98:8850-8855.

De Strooper B, Vassar R, Golde T (2010) The secretases: enzymes with therapeutic potential in Alzheimer disease. Nat Rev Neurol 6:99-107.

El Khoury J, Toft M, Hickman SE, Means TK, Terada K, Geula C, Luster AD (2007) Ccr2 deficiency impairs microglial accumulation and accelerates progression of Alzheimer-like disease. Nat Med 13:432-438.

Forsberg A, Engler H, Almkvist O, Blomquist G, Hagman G, Wall A, Ringheim A, Långström B, Nordberg A (2008) PET imaging of amyloid deposition in patients with mild cognitive impairment. Neurobiol Aging 29:1456-1465.

Garcia-Alloza M, Subramanian M, Thyssen D, Borrelli LA, Fauq A, Das P, Golde TE, Hyman BT, Bacskai BJ (2009) Existing plaques and neuritic abnormalities in APP:PS1 mice are not affected by administration of the $\gamma$-secretase inhibitor LY-411575. Mol Neurodegener 4:19.

Gilman S, et al. (2008) Paper presented at the International Conference on Alzheimer's Disease 12th Annual Meeting, Chicago, IL, July.

Golde TE, Petrucelli L, Lewis J (2010) Targeting A $\beta$ and tau in Alzheimer's disease, an early interim report. Exp Neurol 223:252-266.

Hardy J (2009) The amyloid hypothesis for Alzheimer's disease: a critical reappraisal. J Neurochem 110:1129-1134.

Hardy JA, Higgins GA (1992) Alzheimer's disease: the amyloid cascade hypothesis. Science 256:184-185.

Hartman RE, Izumi Y, Bales KR, Paul SM, Wozniak DF, Holtzman DM (2005) Treatment with an amyloid- $\beta$ antibody ameliorates plaque load, learning deficits, and hippocampal long-term potentiation in a mouse model of Alzheimer's disease. J Neurosci 25:6213-6220.

Hirata-Fukae C, Li HF, Hoe HS, Gray AJ, Minami SS, Hamada K, Niikura T, Hua F, Tsukagoshi-Nagai H, Horikoshi-Sakuraba Y, Mughal M, Rebeck GW, LaFerla FM, Mattson MP, Iwata N, Saido TC, Klein WL, Duff KE, Aisen PS, Matsuoka Y (2008) Females exhibit more extensive amyloid, but not tau, pathology in an Alzheimer transgenic model. Brain Res 1216:92-103.

Holmes C, Boche D, Wilkinson D, Yadegarfar G, Hopkins V, Bayer A, Jones RW, Bullock R, Love S, Neal JW, Zotova E, Nicoll JA (2008) Long-term effects of $A \beta 42$ immunisation in Alzheimer's disease: follow-up of a randomised, placebo-controlled phase I trial. Lancet 372:216-223.

Howland DS, Trusko SP, Savage MJ, Reaume AG, Lang DM, Hirsch JD,
Maeda N, Siman R, Greenberg BD, Scott RW, Flood DG (1998) Modulation of secreted $\beta$-amyloid precursor protein and amyloid $\beta$-peptide in brain by cholesterol. J Biol Chem 273:16576-16582.

Jankowsky JL, Xu G, Fromholt D, Gonzales V, Borchelt DR (2003) Environmental enrichment exacerbates amyloid plaque formation in a transgenic mouse model of Alzheimer disease. J Neuropathol Exp Neurol 62:1220-1227.

Jankowsky JL, Slunt HH, Gonzales V, Savonenko AV, Wen JC, Jenkins NA, Copeland NG, Younkin LH, Lester HA, Younkin SG, Borchelt DR (2005) Persistent amyloidosis following suppression of $A \beta$ production in a transgenic model of Alzheimer's disease. PLoS Med 2:e355.

Jankowsky JL, Younkin LH, Gonzales V, Fadale DJ, Slunt HH, Lester HA, Younkin SG, Borchelt DR (2007) Rodent A $\beta$ modulates the solubility and distribution of amyloid deposits in transgenic mice. J Biol Chem 282:22707-22720.

Jucker M, Heppner FL (2008) Cerebral and peripheral amyloid phagocytes - an old liaison with a new twist. Neuron 59:8-10.

Karlnoski RA, Rosenthal A, Kobayashi D, Pons J, Alamed J, Mercer M, Li Q, Gordon MN, Gottschall PE, Morgan D (2009) Suppression of amyloid deposition leads to long-term reductions in Alzheimer's pathologies in Tg2576 mice. J Neurosci 29:4964-4971.

Kellner A, Matschke J, Bernreuther C, Moch H, Ferrer I, Glatzel M (2009) Autoantibodies against $\beta$-amyloid are common in Alzheimer's disease and help control plaque burden. Ann Neurol 65:24-31.

Koenigsknecht-Talboo J, Meyer-Luehmann M, Parsadanian M, GarciaAlloza M, Finn MB, Hyman BT, Bacskai BJ, Holtzman DM (2008) Rapid microglial response around amyloid pathology after systemic anti-A $\beta$ antibody administration in PDAPP mice. J Neurosci 28:14156-14164.

Kuchibhotla KV, Goldman ST, Lattarulo CR, Wu HY, Hyman BT, Bacskai BJ (2008) $\mathrm{A} \beta$ plaques lead to aberrant regulation of calcium homeostasis in vivo resulting in structural and functional disruption of neuronal networks. Neuron 59:214-225.

Lazarov O, Robinson J, Tang YP, Hairston IS, Korade-Mirnics Z, Lee VM, Hersh LB, Sapolsky RM, Mirnics K, Sisodia SS (2005) Environmental enrichment reduces $A \beta$ levels and amyloid deposition in transgenic mice. Cell 120:701-713.

Le R, Cruz L, Urbanc B, Knowles RB, Hsiao-Ashe K, Duff K, Irizarry MC, Stanley HE, Hyman BT (2001) Plaque-induced abnormalities in neurite geometry in transgenic models of Alzheimer disease: implications for neural system disruption. J Neuropathol Exp Neurol 60:753-758.

Lee EB, Leng LZ, Lee VM, Trojanowski JQ (2005) Meningoencephalitis associated with passive immunization of a transgenic murine model of Alzheimer's amyloidosis. FEBS Lett 579:2564-2568.

Lehman EJ, Kulnane LS, Gao Y, Petriello MC, Pimpis KM, Younkin L, Dolios G, Wang R, Younkin SG, Lamb BT (2003) Genetic background regulates $\beta$-amyloid precursor protein processing and $\beta$-amyloid deposition in the mouse. Hum Mol Genet 12:2949-2956.

Levin-Allerhand JA, Lominska CE, Smith JD (2002) Increased amyloidlevels in APPswe transgenic mice treated chronically with a physiological high-fat high-cholesterol diet. J Nutr Health Aging 6:315-319.

Levites Y, Das P, Price RW, Rochette MJ, Kostura LA, McGowan EM, Murphy MP, Golde TE (2006a) Anti-A $\beta 42$ - and anti-A $\beta 40$-specific mAbs attenuate amyloid deposition in an Alzheimer disease mouse model. J Clin Invest 116:193-201.

Levites Y, Smithson LA, Price RW, Dakin RS, Yuan B, Sierks MR, Kim J, McGowan E, Reed DK, Rosenberry TL, Das P, Golde TE (2006b) Insights into the mechanisms of action of anti- $\mathrm{A} \beta$ antibodies in Alzheimer's disease mouse models. FASEB J 20:2576-2578.

Lim GP, Calon F, Morihara T, Yang F, Teter B, Ubeda O, Salem N Jr, Frautschy SA, Cole GM (2005) A diet enriched with the omega-3 fatty acid docosahexaenoic acid reduces amyloid burden in an aged Alzheimer mouse model. J Neurosci 25:3032-3040.

Lombardo JA, Stern EA, McLellan ME, Kajdasz ST, Hickey GA, Bacskai BJ, Hyman BT (2003) Amyloid- $\beta$ antibody treatment leads to rapid normalization of plaque-induced neuritic alterations. J Neurosci 23:10879-10883.

Maeda J, Ji B, Irie T, Tomiyama T, Maruyama M, Okauchi T, Staufenbiel M, Iwata N, Ono M, Saido TC, Suzuki K, Mori H, Higuchi M, Suhara T (2007) Longitudinal, quantitative assessment of amyloid, neuroinflammation, and anti-amyloid treatment in a living mouse model of Alzheimer's disease enabled by positron emission tomography. J Neurosci 27:10957-10968. 
Mayer SC, Kreft AF, Harrison B, Abou-Gharbia M, Antane M, Aschmies S, Atchison K, Chlenov M, Cole DC, Comery T, Diamantidis G, Ellingboe J, Fan K, Galante R, Gonzales C, Ho DM, Hoke ME, Hu Y, Huryn D, Jain U, et al. (2008) Discovery of begacestat, a Notch-1-sparing $\gamma$-secretase inhibitor for the treatment of Alzheimer's disease. J Med Chem 51:7348-7351.

Mayford M, Bach ME, Huang YY, Wang L, Hawkins RD, Kandel ER (1996) Control of memory formation through regulated expression of a CaMKII transgene. Science 274:1678-1683.

Meyer-Luehmann M, Spires-Jones TL, Prada C, Garcia-Alloza M, de Calignon A, Rozkalne A, Koenigsknecht-Talboo J, Holtzman DM, Bacskai BJ, Hyman BT (2008) Rapid appearance and local toxicity of amyloid- $\beta$ plaques in a mouse model of Alzheimer's disease. Nature 451:720-724.

Nicoll JA, Wilkinson D, Holmes C, Steart P, Markham H, Weller RO (2003) Neuropathology of human Alzheimer disease after immunization with amyloid- $\beta$ peptide: a case report. Nat Med 9:448 -452 .

Nicoll JA, Barton E, Boche D, Neal JW, Ferrer I, Thompson P, Vlachouli C, Wilkinson D, Bayer A, Games D, Seubert P, Schenk D, Holmes C (2006) $\mathrm{A} \beta$ species removal after $\mathrm{A} \beta 42$ immunization. J Neuropathol Exp Neurol 65:1040-1048.

Oddo S, Billings L, Kesslak JP, Cribbs DH, LaFerla FM (2004) A $\beta$ immunotherapy leads to clearance of early, but not late, hyperphosphorylated tau aggregates via the proteasome. Neuron 43:321-332.

Okello A, Koivunen J, Edison P, Archer HA, Turkheimer FE, Nagren K, Bullock R, Walker Z, Kennedy A, Fox NC, Rossor MN, Rinne JO, Brooks DJ (2009) Conversion of amyloid positive and negative MCI to AD over 3 years. An ${ }^{11}$ C-PIB PET study. Neurology 73:754-760.

Oksman M, Iivonen H, Hogyes E, Amtul Z, Penke B, Leenders I, Broersen L, Lütjohann D, Hartmann T, Tanila H (2006) Impact of different saturated fatty acid, polyunsaturated fatty acid and cholesterol containing diets on $\beta$-amyloid accumulation in APP/PS1 transgenic mice. Neurobiol Dis 23:563-572.

Ondrejcak T, Klyubin I, Hu NW, Barry AE, Cullen WK, Rowan MJ (2010) Alzheimer's disease amyloid $\beta$-protein and synaptic function. Neuromolecular Med 12:13-26.

Orgogozo JM, Gilman S, Dartigues JF, Laurent B, Puel M, Kirby LC, Jouanny P, Dubois B, Eisner L, Flitman S, Michel BF, Boada M, Frank A, Hock C (2003) Subacute meningoencephalitis in a subset of patients with AD after A $\beta 42$ immunization. Neurology 61:46-54.

Palop JJ, Mucke L (2010) Amyloid- $\beta$-induced neuronal dysfunction in Alzheimer's disease: from synapses toward neural networks. Nat Neurosci 13:812-818.

Patel NV, Gordon MN, Connor KE, Good RA, Engelman RW, Mason J, Morgan DG, Morgan TE, Finch CE (2005) Caloric restriction attenuates $\mathrm{A} \beta$-deposition in Alzheimer transgenic models. Neurobiol Aging 26:995-1000.

Pfeifer M, Boncristiano S, Bondolfi L, Stalder A, Deller T, Staufenbiel M, Mathews PM, Jucker M (2002) Cerebral hemorrhage after passive anti-A $\beta$ immunotherapy. Science 298:1379.

Poduslo JF, Ramakrishnan M, Holasek SS, Ramirez-Alvarado M, Kandimalla KK, Gilles EJ, Curran GL, Wengenack TM (2007) In vivo targeting of antibody fragments to the nervous system for Alzheimer's disease immunotherapy and molecular imaging of amyloid plaques. J Neurochem 102:420-433.

Praticò D, Uryu K, Sung S, Tang S, Trojanowski JQ, Lee VM (2002) Aluminum modulates brain amyloidosis through oxidative stress in APP transgenic mice. FASEB J 16:1138-1140.

Rabinovici GD, Jagust WJ (2009) Amyloid imaging in aging and dementia: testing the amyloid hypothesis in vivo. Behav Neurol 21:117-128.

Racke MM, Boone LI, Hepburn DL, Parsadainian M, Bryan MT, Ness DK, Piroozi KS, Jordan WH, Brown DD, Hoffman WP, Holtzman DM, Bales KR, Gitter BD, May PC, Paul SM, DeMattos RB (2005) Exacerbation of cerebral amyloid angiopathy-associated microhemorrhage in amyloid precursor protein transgenic mice by immunotherapy is dependent on antibody recognition of deposited forms of amyloid $\beta$. J Neurosci 25:629-636.

Raymond SB, Treat LH, Dewey JD, McDannold NJ, Hynynen K, Bacskai BJ (2008) Ultrasound enhanced delivery of molecular imaging and therapeutic agents in Alzheimer's disease mouse models. PLoS One 3:e2175.

Rinne JO, Brooks DJ, Rossor MN, Fox NC, Bullock R, Klunk WE, Mathis CA, Blennow K, Barakos J, Okello AA, Rodriguez Martinez de Liano S, Liu E, Koller M, Gregg KM, Schenk D, Black R, Grundman M (2010) ${ }^{11} \mathrm{C}-\mathrm{PiB}$ PET assessment of change in fibrillar amyloid- $\beta$ load in patients with
Alzheimer's disease treated with bapineuzumab: a phase 2, double-blind, placebo-controlled, ascending-dose study. Lancet Neurol 9:363-372.

Rogers AB, Cormier KS, Fox JG (2006) Thiol-reactive compounds prevent nonspecific antibody binding in immunohistochemistry. Lab Invest 86:526-533.

Salloway S, Sperling R, Gilman S, Fox NC, Blennow K, Raskind M, Sabbagh M, Honig LS, Doody R, van Dyck CH, Mulnard R, Barakos J, Gregg KM, Liu E, Lieberburg I, Schenk D, Black R, Grundman M; Bapineuzumab 201 Clinical Trial Investigators (2009) A phase 2 multiple ascending dose trial of bapineuzumab in mild to moderate Alzheimer disease. Neurology 73 : 2061-2071.

Schenk D, Barbour R, Dunn W, Gordon G, Grajeda H, Guido T, Hu K, Huang J, Johnson-Wood K, Khan K, Kholodenko D, Lee M, Liao Z, Lieberburg I, Motter R, Mutter L, Soriano F, Shopp G, Vasquez N, Vandevert C, et al. (1999) Immunization with amyloid- $\beta$ attenuates Alzheimer-disease-like pathology in the PDAPP mouse. Nature 400:173-177.

Schroeter S, Khan K, Barbour R, Doan M, Chen M, Guido T, Gill D, Basi G, Schenk D, Seubert P, Games D (2008) Immunotherapy reduces vascular amyloid- $\beta$ in PDAPP mice. J Neurosci 28:6787-6793.

Shankar GM, Walsh DM (2009) Alzheimer's disease: synaptic dysfunction and $\mathrm{A} \beta$. Mol Neurodegener 4:48.

Simard AR, Soulet D, Gowing G, Julien JP, Rivest S (2006) Bone marrowderived microglia play a critical role in restricting senile plaque formation in Alzheimer's disease. Neuron 49:489-502.

Stern EA, Bacskai BJ, Hickey GA, Attenello FJ, Lombardo JA, Hyman BT (2004) Cortical synaptic integration in vivo is disrupted by amyloid- $\beta$ plaques. J Neurosci 24:4535-4540.

Thakker DR, Weatherspoon MR, Harrison J, Keene TE, Lane DS, Kaemmerer WF, Stewart GR, Shafer LL (2009) Intracerebroventricular amyloid- $\beta$ antibodies reduce cerebral amyloid angiopathy and associated microhemorrhages in aged Tg2576 mice. Proc Natl Acad Sci U S A 106:4501-4506.

Tsai J, Grutzendler J, Duff K, Gan WB (2004) Fibrillar amyloid deposition leads to local synaptic abnormalities and breakage of neuronal branches. Nat Neurosci 7:1181-1183.

Wang J, Tanila H, Puoliväli J, Kadish I, van Groen T (2003) Gender differences in the amount and deposition of amyloid- $\beta$ in APPswe and PS1 double transgenic mice. Neurobiol Dis 14:318-327.

Wilcock DM, DiCarlo G, Henderson D, Jackson J, Clarke K, Ugen KE, Gordon MN, Morgan D (2003) Intracranially administered anti-A $\beta$ antibodies reduce $\beta$-amyloid deposition by mechanisms both independent of and associated with microglial activation. J Neurosci 23:3745-3751.

Wilcock DM, Munireddy SK, Rosenthal A, Ugen KE, Gordon MN, Morgan D (2004a) Microglial activation facilitates $A \beta$ plaque removal following intracranial anti- $\mathrm{A} \beta$ antibody administration. Neurobiol Dis 15:11-20.

Wilcock DM, Rojiani A, Rosenthal A, Levkowitz G, Subbarao S, Alamed J, Wilson D, Wilson N, Freeman MJ, Gordon MN, Morgan D (2004b) Passive amyloid immunotherapy clears amyloid and transiently activates microglia in a transgenic mouse model of amyloid deposition. J Neurosci 24:6144-6151.

Wilcock DM, Rojiani A, Rosenthal A, Subbarao S, Freeman MJ, Gordon MN, Morgan D (2004c) Passive immunotherapy against $A \beta$ in aged APP-transgenic mice reverses cognitive deficits and depletes parenchymal amyloid deposits in spite of increased vascular amyloid and microhemorrhage. J Neuroinflammation 1:24.

Wilcock DM, Alamed J, Gottschall PE, Grimm J, Rosenthal A, Pons J, Ronan V, Symmonds K, Gordon MN, Morgan D (2006) Deglycosylated antiamyloid- $\beta$ antibodies eliminate cognitive deficits and reduce parenchymal amyloid with minimal vascular consequences in aged amyloid precursor protein transgenic mice. J Neurosci 26:5340-5346.

Wilcock DM, Jantzen PT, Li Q, Morgan D, Gordon MN (2007) Amyloid- $\beta$ vaccination, but not nitro-nonsteroidal anti-inflammatory drug treatment, increases vascular amyloid and microhemorrhage while both reduce parenchymal amyloid. Neuroscience 144:950-960.

Winkler DT, Abramowski D, Danner S, Zurini M, Paganetti P, Tolnay M, Staufenbiel M (2010) Rapid cerebral amyloid binding by $A \beta$ antibodies infused into $\beta$-amyloid precursor protein transgenic mice. Biol Psychiatry 68:971-974.

Wolk DA, Price JC, Saxton JA, Snitz BE, James JA, Lopez OL, Aizenstein HJ, Cohen AD, Weissfeld LA, Mathis CA, Klunk WE, De-Kosky ST (2009) Amyloid imaging in mild cognitive impairment subtypes. Ann Neurol 65:557-568 